\title{
Cardiovascular Risk Management and Hepatitis C: Combining Drugs
}

\author{
Elise J. Smolders ${ }^{1,2}$ (D) Peter J. G. ter Horst ${ }^{1}\left[\right.$ - Sharon Wolters ${ }^{1} \cdot$ David M. Burger $^{2}$
}

Published online: 27 September 2018

(c) The Author(s) 2018

\begin{abstract}
Direct-acting antivirals (DAAs) are known victims (substrate) and perpetrators (cause) of drug-drug interactions (DDIs). These DAAs are used for the treatment of hepatitis C virus (HCV) infections and are highly effective drugs. Drugs used for cardiovascular risk management are frequently used by $\mathrm{HCV}$-infected patients, whom also are treated with DAAs. Therefore, the aim of this review was to describe DDIs between cardiovascular drugs (CVDs) and DAAs. An extensive literature search was performed containing search terms for the marketed DAAs and CVDs ( $\beta$-blocking agents, ACE inhibitors, angiotensin II antagonists, renin inhibitors, diuretics, calcium channel blockers, statins/ezetimibe, fibrates, platelet aggregation inhibitors, vitamin $\mathrm{K}$ antagonists, heparins, direct Xa inhibitors, nitrates, amiodarone, and digoxin). In particular, the drug labels from the European Medicines Agency and the US Food and Drug Administration were used. A main finding of this review is that CVDs are mostly victims of DDIs with DAAs. Therefore, when possible, monitoring of pharmacodynamics is recommended when coadministering these drugs with DAAs. Nevertheless, it is sometimes better to discontinue a drug on a temporary basis (statins, ezetimide). The DAAs are victims of DDIs in combination with bisoprolol, carvedilol, labetalol, verapamil, and gemfibrozil. Despite there are many DDIs predicted in this review, most of these DDIs can be managed by monitoring the efficacy and toxicity of the victim drug or by switching to another CVD/DAA.
\end{abstract}

\section{Key Points}

Drug-drug interactions (DDIs) can be of major concern in hepatitis $\mathrm{C}$ patients with cardiovascular issues as there are many potential DDIs.

Especially clopidogrel and ticagrelor are drugs of which the potential drug-interactions are complex and hard to manage.

With increasing number of new direct-acting antivirals (DAAs) available the number clinical relevant DDIs are decreasing.
Elise J. Smolders

Elise.Smolders@radboudumc.nl

1 Department of Pharmacy, Isala Hospital, Dokter van Heesweg 2, 8025 AB Zwolle, The Netherlands

2 Department of Pharmacy, Radboud university medical center, Geert Grooteplein Zuid 10, 6525 GA Nijmegen, The Netherlands

\section{Introduction}

Direct-acting antivirals (DAAs) used for the treatment of a chronic hepatitis $\mathrm{C}$ virus (HCV) infection are known for their drug-interacting potential. They are both substrates and inhibitors/inducers of drug-metabolizing enzymes and drug transporters, making them victims and perpetrators of drug-drug interactions (DDIs) [1-3].

Numerous papers have shown that HCV patients are polypharmacy patients, meaning that they use high numbers of drugs and a diverse combination of medications [4-7]. This includes the usual suspects that we would expect in HCVinfected patients, such as immunosuppressive agents (liver transplantation), antiretroviral agents (HIV co-infection), and psychoactive medications, because of the high incidence of mental illnesses. However, drugs used for cardiovascular risk management are also frequently used by $\mathrm{HCV}$-infected patients, e.g., statins (HMG-CoA reductase inhibitors), anticoagulant agents, and antihypertensive drugs [4-7]. We can explain this by the fact that we are now treating aging HCVinfected patients, and polypharmacy has a positive correlation with age [6-8]. In addition, extrahepatic manifestations associated with HCV such as diabetes mellitus and renal and cardiovascular disease could be an explanation for the use of these kinds of drugs $[9,10]$. 
To date, there are no published reviews in the literature concerning DDIs between cardiovascular drugs (CVDs) and DAAs, despite the fact that cardiovascular agents are one of the most frequently prescribed drugs [4]. For drug interactions with DAAs, the scientific community has focused on the most commonly prescribed drugs in HCV patients. However, in daily practice, clinical pharmacists are frequently asked many questions about combining DAAs with anticoagulation agents, ACE inhibitors, $\beta$-blockers, and statins. Some interactions are easy to manage (monitoring blood pressure), whereas others are highly complex due to the metabolic profile of the DAAs and the CVD (e.g., clopidogrel). This is, for instance, reported by de Lorenzo-Pinto et al. [11], who reported a significantly increased acenocoumarol dose because of the interaction with paritraprevir/ritonavir, ombitasvir, and dasabuvir (PrOD). Comparable interaction was seen with warfarin, resulting in a subtherapeutic international normalized ratio (INR) during concomitant treatment with PrOD [11]. Both of these cases showed that there were significant DDIs between anticoagulants and PrOD, making increased monitoring necessary. Other case reports describing severe bradycardia, which even caused death, were reported in patients using amiodarone in combination with sofosbuvir and NS5A inhibitors. This was an unexpected DDI, showing that not all DDIs can be predicted $[12,13]$.

This review aims to provide clinical guidance to cardiologists managing CVDs when patients are treated with DAAs, hepatologists/infectious disease specialists, and also to other physicians, such as general practitioners, who are now allowed to prescribe the DAAs. All of these physicians should have detailed knowledge of the pharmacotherapy of both disease areas and should be able to choose the appropriate DAA regimen with the least number of DDIs for these patients. The review begins by describing the drug metabolism of DAAs and CVDs and presenting the in vivo drug interactions found in the literature. Next, drug interactions between DAAs and CVDs are predicted based on drug metabolism and drug transport, which are accompanied with recommendations for clinical decision-making.

\section{Methods}

The DAAs included in this descriptive review are the protease inhibitors grazoprevir, glecaprevir, paritaprevir, simeprevir, and voxilaprevir, the NS5A inhibitors daclatasvir, elbasvir, pibrentasvir, ledipasvir, ombitasvir, and velpatasvir, and the NS5B polymerase inhibitors dasabuvir and sofosbuvir.

The CVDs included can be grouped into the following classes: antihypertensive agents, anticoagulation agents, antithrombotic agents, antiarrhythmic agents, and lipidlowering agents. All included drugs are listed in Table 1.
For this review, we aimed to select the most commonly prescribed agents in Europe and the USA. This selection was based on clinical experience of the pharmacists EJS, PJGtH, and DMB.

An extensive literature search was performed in January 2018. Search terms contained both generic and brand names of the selected drugs given in Tables 1 and 2 and all searches were performed in English. These drug names were combined with the search terms 'drug-drug interaction' or 'pharmacokinetics'. We searched PubMed (1946-January 2018) to identify peer-reviewed studies. In addition, information from the Summary of Product Characteristics (SmPC) approved by the European Medicines Agency (EMA) and the Prescribing Information approved by the US Food and Drug Administration (FDA) were used. The Google and Google Scholar search engines, ClinicalTrials.gov (http:// www.clinicaltrials.gov) website, and the Liverpool drug interaction database (http://www.hep-druginteractions.org) were also used to identify conference posters and abstracts.

\section{Understanding Drug-Drug Interactions}

To understand and predict DDIs, knowledge of pharmacokinetics and pharmacodynamics is crucial. Pharmacokinetics is described by the absorption (after oral administration), distribution, metabolism, and elimination (ADME) of a drug (Fig. 1). The goal during drug therapy is to maintain the plasma concentration within a therapeutic range (therapeutic window), which balances efficacy and toxicity (Fig. 2a). Pharmacogenetic variations in drug-metabolizing enzymes and drug transporters (polymorphisms), food and lifestyle, adherence to drugs, or drug interactions can result in variable plasma concentrations of drugs (inter-subject variability). Concerning drug interactions, these can take place at all the four phases of ADME, altering the pharmacokinetic profile of another drug (Fig. 3). In this review, we focus particularly on this type of pharmacokinetic drug interaction.

The most important drug-metabolizing enzymes for DDIs are phase I (cytochrome P450 [CYP] enzymes) and phase II (uridine 5'-diphospho-glucuronosyltransferase [UGT] enzymes [conjugation]). These enzymes can be inhibited and induced by other drugs (perpetrators) influencing the plasma concentration of the substrate (victim drug) (Fig. 1). Comparably, influx and efflux drug transporters are involved in drug interactions as they can also be inhibited or induced by other drugs. Also, the location of the transporter and the direction of transport determine the net result of the drug interaction (substrates plasma concentration) [14].

For both enzymes and transporters, several polymorphisms are known that are genetic variations influencing the activity of the affected enzyme or transporter. For example, for CYP2D6 several phenotypic polymorphisms are 
Table 1 Drug-metabolizing enzymes and drug transporters involved in the metabolism and distribution of a selection of cardiovascular drugs

\begin{tabular}{|c|c|c|c|c|c|c|}
\hline \multirow{2}{*}{$\begin{array}{l}\text { Drug (therapeutic range } \\
\text { or drug concentration) }\end{array}$} & \multicolumn{2}{|l|}{ Phase I metabolism } & \multirow[t]{2}{*}{ Phase II metabolism } & \multicolumn{2}{|l|}{ Drug-transporter } & \multirow[t]{2}{*}{ References } \\
\hline & Substrate & Inhibitor & & Substrate & Inhibitor & \\
\hline \multicolumn{7}{|l|}{$\beta$-Blocking agents } \\
\hline $\begin{array}{l}\text { Atenolol }^{\mathrm{a}} \text { (decreases in } \\
\text { blood pressure are not } \\
\text { correlated with serum } \\
\text { concentrations) }\end{array}$ & & & & & & [77] \\
\hline $\begin{array}{l}\text { Bisoprolol (range } \\
0.01-0.1 \mu \mathrm{g} / \mathrm{mL} \text {; no } \\
\text { correlation between } \\
\text { plasma concentrations } \\
\text { and clinical efficacy) }\end{array}$ & $\begin{array}{l}\text { CYP3A4 (major) } \\
\text { CYP2D6 (minor) }\end{array}$ & & & & & {$[78]$} \\
\hline $\begin{array}{l}\text { Carvedilol (range not } \\
\text { defined) }\end{array}$ & $\begin{array}{l}\text { CYP2D6 (major) } \\
\text { CYP1A2 (minor) } \\
\text { CYP2C9 (minor) } \\
\text { CYP2E1 (minor) } \\
\text { CYP3A4 (minor) } \\
\text { CYP2C19 }\end{array}$ & & Glucuronidation & P-gp & P-gp & {$[16]$} \\
\hline $\begin{array}{l}\text { Labetalol (range not } \\
\text { defined) }\end{array}$ & Glucuronidation & & & & & [79] \\
\hline $\begin{array}{l}\text { Metoprolol (range } \\
35-212 \mathrm{ng} / \mathrm{mL})\end{array}$ & $\begin{array}{l}\text { CYP2D6 (major) } \\
\text { CYP2C19 (minor) }\end{array}$ & & & & & {$[80]$} \\
\hline $\begin{array}{l}\text { Nebivolol (range not } \\
\text { defined) }\end{array}$ & $\begin{array}{l}\text { CYP2D6 (minor) } \\
\text { Glucuronidation }\end{array}$ & & & & & [81] \\
\hline $\begin{array}{l}\text { Propranolol (range } \\
20-85 \mathrm{ng} / \mathrm{mL} \text { ) }\end{array}$ & $\begin{array}{l}\text { CYP1A2 (major) } \\
\text { CYP2D6 (major) } \\
\text { CYP2C19 (minor) } \\
\text { CYP3A4 (minor) }\end{array}$ & $\begin{array}{l}\text { CYP1A2 (weak) } \\
\text { CYP2D6 (weak) }\end{array}$ & & P-gp & & {$[82]$} \\
\hline $\begin{array}{l}\text { Sotalol }^{\mathrm{a}} \text { (range not } \\
\text { defined) }\end{array}$ & & & & & & {$[83]$} \\
\hline \multicolumn{7}{|l|}{ ACE inhibitors } \\
\hline $\begin{array}{l}\text { Captopril (range } \\
0.05-0.5 \mu \mathrm{g} / \mathrm{mL} \text { ) }\end{array}$ & CYP2D6 (major) & & & & & [84] \\
\hline $\begin{array}{l}\text { Enalapril }^{\mathrm{a}} \text { (range } \\
0.01-0.05 \mu \mathrm{g} / \mathrm{mL} \text { ) }\end{array}$ & & & & $\begin{array}{l}\text { OATP1B1 } \\
\text { OATP1B3 MRP2 }\end{array}$ & & {$[27,85]$} \\
\hline $\begin{array}{l}\text { Fosinopril }^{\mathrm{a}} \text { (range not } \\
\text { defined) }\end{array}$ & & & & & & [86] \\
\hline Lisinopril $^{\mathrm{a}}(1-5 \mathrm{ng} / \mathrm{mL})$ & & & & & & [87] \\
\hline $\begin{array}{l}\text { Perindopril (range not } \\
\text { defined) }\end{array}$ & & & Glucuronidation & & & {$[88]$} \\
\hline $\begin{array}{l}\text { Quinapril b }^{\mathrm{b}} \text { (range not } \\
\text { defined) }\end{array}$ & & & & & & [89] \\
\hline $\begin{array}{l}\operatorname{Ramipril}^{\mathrm{b}}(\text { range } \\
0.001-0.01 \mu \mathrm{g} / \mathrm{mL})\end{array}$ & & & & & & {$[90]$} \\
\hline \multicolumn{7}{|c|}{ Angiotensin II antagonists and renin inhibitors } \\
\hline $\begin{array}{l}\text { Candesartan (range not } \\
\text { defined) }\end{array}$ & CYP2C9 (minor) & $\begin{array}{l}\text { CYP2C8 (weak) } \\
\text { CYP2C9 (weak) }\end{array}$ & & & & [91] \\
\hline $\begin{array}{l}\text { Irbesartan (range not } \\
\text { defined) }\end{array}$ & $\begin{array}{l}\text { CYP2C9 (minor) } \\
\text { Glucuronidation }\end{array}$ & $\begin{array}{l}\text { CYP2C8 (moderate) } \\
\text { CYP2C9 (moderate) }\end{array}$ & & $\begin{array}{l}\text { OATP1B1 } \\
\text { OATP1B3 }\end{array}$ & & {$[30,92,93]$} \\
\hline $\begin{array}{l}\text { Losartan (range not } \\
\text { defined) }\end{array}$ & $\begin{array}{l}\text { CYP2C9 (major) } \\
\text { CYP3A4 (major) }\end{array}$ & $\begin{array}{l}\text { CYP2C8 (moderate) } \\
\text { CYP2C9 (moderate) }\end{array}$ & & & & {$[32]$} \\
\hline $\begin{array}{l}\text { Olmesartan (range not } \\
\text { defined) }\end{array}$ & & & & OATP1B1 & & [94] \\
\hline $\begin{array}{l}\text { Telmisartan (range not } \\
\text { defined) }\end{array}$ & & & & $\begin{array}{l}\text { OATP1B1 } \\
\text { OATP1B3 }\end{array}$ & & {$[31,95]$} \\
\hline
\end{tabular}


Table 1 (continued)

\begin{tabular}{|c|c|c|c|c|c|c|}
\hline \multirow{2}{*}{$\begin{array}{l}\text { Drug (therapeutic range } \\
\text { or drug concentration) }\end{array}$} & \multicolumn{2}{|l|}{ Phase I metabolism } & \multirow[t]{2}{*}{ Phase II metabolism } & \multicolumn{2}{|c|}{ Drug-transporter } & \multirow[t]{2}{*}{ References } \\
\hline & Substrate & Inhibitor & & Substrate & Inhibitor & \\
\hline $\begin{array}{l}\text { Valsartan (range not } \\
\text { defined) }\end{array}$ & CYP2C9 & CYP2C9 (weak) & & $\begin{array}{l}\text { OATP1B1 } \\
\text { OATP1B3 } \\
\text { MRP2 }\end{array}$ & & {$[81,96]$} \\
\hline $\begin{array}{l}\text { Aliskiren (range not } \\
\text { defined) }\end{array}$ & CYP3A4 (minor) & & & $\begin{array}{l}\text { P-gp } \\
\text { OATP1B1 }\end{array}$ & P-gp & {$[33-36,97]$} \\
\hline \multicolumn{7}{|l|}{ Diuretics } \\
\hline $\begin{array}{l}\text { Amiloride (no correla- } \\
\text { tion between therapeu- } \\
\text { tic effects and serum } \\
\text { concentrations) }\end{array}$ & & & & OCT & & [98] \\
\hline $\begin{array}{l}\text { Bumetanide }{ }^{c} \text { (range not } \\
\text { defined) }\end{array}$ & & & & & & [99] \\
\hline $\begin{array}{l}\text { Chlorothiazide }^{\mathrm{a}} \text { (range } \\
\text { not defined) }\end{array}$ & & & & & & {$[100]$} \\
\hline \multicolumn{7}{|l|}{$\begin{array}{l}\text { Chlorthalidone }^{c} \text { (range } \\
\text { not defined) }\end{array}$} \\
\hline $\begin{array}{l}\text { Eplerenone (range not } \\
\text { defined) }\end{array}$ & CYP3A4 (major) & & & & & {$[38]$} \\
\hline $\begin{array}{l}\text { Furosemide (no rela- } \\
\text { tion between plasma } \\
\text { concentrations and } \\
\text { therapeutic effect. } \\
\text { Response is related to } \\
\text { the urine concentra- } \\
\text { tion) }\end{array}$ & & & Glucuronidation & OAT3 & MRP2 & [101] \\
\hline $\begin{array}{l}\text { Hydrochlorothiazide } \\
\text { (no correlation } \\
\text { between blood } \\
\text { pressure and serum } \\
\text { concentrations) }\end{array}$ & & & & & & [92] \\
\hline $\begin{array}{l}\text { Indapamide }^{c} \text { (range not } \\
\text { defined) }\end{array}$ & & & & & & [102] \\
\hline $\begin{array}{l}\text { Spironolactone }^{\mathrm{a}} \text { (range } \\
\text { not defined) }\end{array}$ & & & & & & [103] \\
\hline $\begin{array}{l}\text { Triamterene }^{\mathrm{a}} \text { (range not } \\
\text { defined) }\end{array}$ & & & & & & [104] \\
\hline \multicolumn{7}{|l|}{ Calcium channel blockers } \\
\hline $\begin{array}{l}\text { Amlodipine (range not } \\
\text { defined) }\end{array}$ & CYP3A4 (major) & $\begin{array}{l}\text { CYP2A6 (weak) } \\
\text { CYP2C8 (weak) } \\
\text { CYP2C9 (weak) } \\
\text { CYP3A4 (weak) }\end{array}$ & & & BCRP & {$[96,105]$} \\
\hline $\begin{array}{l}\text { Barnidipine (range not } \\
\text { defined) }\end{array}$ & CYP3A4 & & & & & [106] \\
\hline $\begin{array}{l}\text { Diltiazem (range } \\
40-200 \mathrm{ng} / \mathrm{mL})\end{array}$ & $\begin{array}{l}\text { CYP3A4 (major) } \\
\text { CYP2C9 (minor) } \\
\text { CYP2D6 (minor) }\end{array}$ & $\begin{array}{l}\text { CYP3A4 (moderate) } \\
\text { CYP2C9 (weak) } \\
\text { CYP2D6 (weak) }\end{array}$ & & P-gp & P-gp & [107] \\
\hline $\begin{array}{l}\text { Felodipine (range } \\
0.001-0.0012 \mu \mathrm{g} / \mathrm{mL} \text { ) }\end{array}$ & CYP3A4 (major) & $\begin{array}{l}\text { CYP2C8 (moderate) } \\
\text { CYP2C9 (weak) } \\
\text { CYP2D6 (weak) }\end{array}$ & & & BCRP & [108] \\
\hline $\begin{array}{l}\text { Lercanidipine (range not } \\
\text { defined) }\end{array}$ & CYP3A4 & $\begin{array}{l}\text { CYP3A4 (strong) } \\
\text { CYP2D6 }\end{array}$ & & & P-gp & [109] \\
\hline
\end{tabular}


Table 1 (continued)

\begin{tabular}{|c|c|c|c|c|c|c|}
\hline \multirow{2}{*}{$\begin{array}{l}\text { Drug (therapeutic range } \\
\text { or drug concentration) }\end{array}$} & \multicolumn{2}{|l|}{ Phase I metabolism } & \multirow[t]{2}{*}{ Phase II metabolism } & \multicolumn{2}{|c|}{ Drug-transporter } & \multirow[t]{2}{*}{ References } \\
\hline & Substrate & Inhibitor & & Substrate & Inhibitor & \\
\hline $\begin{array}{r}\text { Nicardipine (range } \\
0.07-0.1 \mu \mathrm{g} / \mathrm{mL})\end{array}$ & $\begin{array}{l}\text { CYP3A4 (major) } \\
\text { CYP1A2 (minor) } \\
\text { CYP2C8 (minor) } \\
\text { CYP2C9 (minor) } \\
\text { CYP2D6 (minor) } \\
\text { CYP2E1 (minor) }\end{array}$ & $\begin{array}{l}\text { CYP2C9 (strong) } \\
\text { CYP2D6 (weak) } \\
\text { CYP3A4 (weak) } \\
\text { CYP2C8 } \\
\text { CYP2C19 }\end{array}$ & & P-gp & BCRP & [110] \\
\hline $\begin{array}{l}\text { Nifedipine (range not } \\
\text { defined) }\end{array}$ & $\begin{array}{l}\text { CYP3A4 (major) } \\
\text { CYP2D6 (minor) }\end{array}$ & CYP2C9 (weak) & & & BCRP & [111] \\
\hline $\begin{array}{l}\text { Verapamil (range } \\
0.02-0.25 \mu \mathrm{g} / \mathrm{mL})\end{array}$ & $\begin{array}{l}\text { CYP3A4 (major) } \\
\text { CYP1A2 (minor) } \\
\text { CYP2B6 (minor) } \\
\text { CYP2C9 (minor) } \\
\text { CYP2E1 (minor) }\end{array}$ & $\begin{array}{l}\text { CYP3A4 (moderate) } \\
\text { CYP1A2 (weak) } \\
\text { CYP2C9 (weak) }\end{array}$ & & P-gp & P-gp & [39] \\
\hline \multicolumn{7}{|l|}{ Statins and ezetimibe } \\
\hline $\begin{array}{l}\text { Atorvastatin (no rela- } \\
\text { tion found between } \\
\text { LDL-lowering effects } \\
\text { and systemic drug } \\
\text { concentrations) }\end{array}$ & CYP3A4 (major) & CYP3A4 (weak) & & $\begin{array}{l}\text { P-gp } \\
\text { OATP1B1 }\end{array}$ & & [112] \\
\hline $\begin{array}{l}\text { Ezetimibe (range not } \\
\text { defined) }\end{array}$ & & & Glucuronidation & OATP1B1 & & {$[112,113]$} \\
\hline $\begin{array}{l}\text { Fluvastatin (range not } \\
\text { defined) }\end{array}$ & $\begin{array}{l}\text { CYP2C9 (minor) } \\
\text { CYP2D6 (minor) } \\
\text { CYP3A4 (minor) } \\
\text { CYP2C8 }\end{array}$ & $\begin{array}{l}\text { CYP2C9 (moderate) } \\
\text { CYP2C8 (weak) }\end{array}$ & & OATP1B1 & & \\
\hline $\begin{array}{l}\text { Lovastatin (range not } \\
\text { defined) }\end{array}$ & CYP3A4 (major) & CYP2C9 (weak) & & P-gp & & [114] \\
\hline $\begin{array}{l}\text { Pravastatin (range not } \\
\text { defined) }\end{array}$ & CYP3A4 (minor) & CYP2C9 (weak) & & $\begin{array}{l}\text { P-gp } \\
\text { OATP1B1 }\end{array}$ & & [115] \\
\hline $\begin{array}{l}\text { Rosuvastatin (range not } \\
\text { defined) }\end{array}$ & $\begin{array}{l}\text { CYP2C9 (minor) } \\
\text { CYP3A4 (minor) }\end{array}$ & & & $\begin{array}{l}\text { OATP1B1 } \\
\text { BCRP }\end{array}$ & & [116] \\
\hline $\begin{array}{l}\text { Simvastatin (range not } \\
\text { defined) }\end{array}$ & CYP3A4 (major) & $\begin{array}{l}\text { CYP2C8 (weak) } \\
\text { CYP2C9 (weak) }\end{array}$ & & OATP1B1 & & [113] \\
\hline \multicolumn{7}{|l|}{ Fibrates } \\
\hline $\begin{array}{l}\text { Bezafibrate (range not } \\
\text { defined) }\end{array}$ & CYP3A4 (minor) & & Glucuronidation & & & [117] \\
\hline $\begin{array}{l}\text { Ciprofibrate (range not } \\
\text { defined) }\end{array}$ & & & Glucuronidation & & & [118] \\
\hline $\begin{array}{l}\text { Fenofibrate }^{\mathrm{b}} \text { (range } \\
5-30 \mu \mathrm{g} / \mathrm{mL} \text { ) }\end{array}$ & & $\begin{array}{l}\text { CYP2A6 (weak) } \\
\text { CYP2C8 (weak) } \\
\text { CYP2C9 (weak) }\end{array}$ & Glucuronidation & & & [119] \\
\hline $\begin{array}{l}\text { Gemfibrozil (range not } \\
\text { defined) }\end{array}$ & CYP3A4 (minor) & $\begin{array}{l}\text { CYP2C8 (strong) } \\
\text { CYP2C9 (strong) } \\
\text { UGT1A1 }\end{array}$ & UGT2B7 & & OATP1B1/3 & {$[120]$} \\
\hline \multicolumn{7}{|l|}{ Platelet aggregation inhibitors } \\
\hline $\begin{array}{l}\text { Acetylsalicylic acid } \\
\text { (range not defined as } \\
\text { platelet aggregation } \\
\text { inhibitor) }\end{array}$ & CYP2C9 (minor) & & Glucuronidation & & & {$[121,122]$} \\
\hline $\begin{array}{l}\text { Carbasalate calcium } \\
\text { (range not defined) }\end{array}$ & & & Glucuronidation & & & [123] \\
\hline $\begin{array}{l}\text { Dipyridamole (range not } \\
\text { defined) }\end{array}$ & & & Glucuronidation & & BCRP & [122] \\
\hline
\end{tabular}


Table 1 (continued)

\begin{tabular}{|c|c|c|c|c|c|c|}
\hline \multirow{2}{*}{$\begin{array}{l}\text { Drug (therapeutic range } \\
\text { or drug concentration) }\end{array}$} & \multicolumn{2}{|l|}{ Phase I metabolism } & \multirow[t]{2}{*}{ Phase II metabolism } & \multicolumn{2}{|l|}{ Drug-transporter } & \multirow[t]{2}{*}{ References } \\
\hline & Substrate & Inhibitor & & Substrate & Inhibitor & \\
\hline $\begin{array}{l}\text { Clopidogrel (prodrug) } \\
\text { (range not defined) }\end{array}$ & $\begin{array}{l}\text { CYP2C19 } \\
\text { CYP3A4 } \\
\text { CYP1A2 } \\
\text { CYP2B6 }\end{array}$ & $\begin{array}{l}\text { CYP2C8 (moderate) } \\
\text { CYP2B6 (weak) } \\
\text { CYP2C9 (weak) }\end{array}$ & & & OATP1B1 & {$[52,53]$} \\
\hline $\begin{array}{l}\text { Prasugrel (prodrug) } \\
\text { (range not defined) }\end{array}$ & $\begin{array}{l}\text { CYP2B6 (minor) } \\
\text { CYP3A4 } \\
\text { CYP2C } 9 / 19\end{array}$ & CYP2B6 (weak) & & & & {$[54,55]$} \\
\hline $\begin{array}{l}\text { Ticagrelor (prodrug) } \\
\text { (range not defined) }\end{array}$ & CYP3A4 (major) & $\begin{array}{l}\text { CYP3A4 (weak) } \\
\text { CYP3A5 inducer }\end{array}$ & & P-gp & P-gp & {$[56,124]$} \\
\hline Vitamin $\mathrm{K}$ antagonists & & & & & & \\
\hline $\begin{array}{l}\text { Acenocoumarol (no } \\
\text { relation established } \\
\text { between plasma } \\
\text { concentration and } \\
\text { prothrombin levels) }\end{array}$ & $\begin{array}{l}\text { CYP1A2 (major) } \\
\text { CYP2C9 (major) } \\
\text { CYP2C19 (minor) }\end{array}$ & & & & & {$[125]$} \\
\hline $\begin{array}{l}\text { Phenprocoumon (range } \\
\text { not defined) }\end{array}$ & $\begin{array}{l}\text { CYP2C9 } \\
\text { CYP3A4 }\end{array}$ & & Glucuronidation & & & {$[126]$} \\
\hline $\begin{array}{l}\text { Warfarin (range not } \\
\text { defined) }\end{array}$ & $\begin{array}{l}\text { CYP2C9 (major) } \\
\text { CYP1A2 (minor) } \\
\text { CYP2C19 (minor) } \\
\text { CYP3A4 (minor) } \\
\text { CYP2C8 } \\
\text { CYP2C18 }\end{array}$ & CYP2C9 & & & & {$[127]$} \\
\hline \multicolumn{7}{|c|}{ Heparin group and fondaparinux } \\
\hline $\begin{array}{l}\text { Dalteparin }{ }^{\mathrm{a}} \text { (range not } \\
\text { defined) }\end{array}$ & & & & & & [128] \\
\hline $\begin{array}{l}\text { Enoxaparin }^{\mathrm{d}} \text { (range not } \\
\text { defined) }\end{array}$ & & & & & & [129] \\
\hline $\begin{array}{l}\text { Heparin }^{\mathrm{a}} \text { (range not } \\
\text { defined) }\end{array}$ & & & & & & [130] \\
\hline $\begin{array}{l}\text { Nadroparin }{ }^{\mathrm{a}} \text { (range not } \\
\text { defined) }\end{array}$ & & & & & & [131] \\
\hline $\begin{array}{l}\text { Fondaparinux }{ }^{\mathrm{a}} \text { (range } \\
\text { not defined) }\end{array}$ & & & & & & [132] \\
\hline \multicolumn{7}{|l|}{ Direct factor Xa inhibitors } \\
\hline $\begin{array}{l}\text { Apixaban (range not } \\
\text { defined) }\end{array}$ & $\begin{array}{l}\text { CYP3A4 (major) } \\
\text { CYP1A2 (minor) } \\
\text { CYP2C19 (minor) } \\
\text { CYP2C8 (minor) } \\
\text { CYP2C9 (minor) } \\
\text { CYP2J2 }\end{array}$ & & & $\begin{array}{l}\text { P-gp } \\
\text { BCRP }\end{array}$ & & {$[64,65]$} \\
\hline $\begin{array}{l}\text { Dabigatran (range not } \\
\text { defined) }\end{array}$ & & & Glucuronidation & P-gp & & {$[133,134]$} \\
\hline $\begin{array}{l}\text { Edoxaban (range not } \\
\text { defined) }\end{array}$ & CYP3A4 (minor) & & & $\begin{array}{l}\text { P-gp } \\
\text { OATP 1B1 } \\
\text { (active metabo- } \\
\text { lite) }\end{array}$ & & {$[63,135]$} \\
\hline $\begin{array}{l}\text { Rivaroxaban (range not } \\
\text { defined) }\end{array}$ & $\begin{array}{l}\text { CYP3A4 (major) } \\
\text { CYP2J2 (minor) } \\
\text { CYP3A5 }\end{array}$ & & & $\begin{array}{l}\text { BCRP } \\
\text { P-gp }\end{array}$ & & {$[136,137]$} \\
\hline \multicolumn{7}{|l|}{ Nitrates } \\
\hline $\begin{array}{l}\text { Glyceryl trinitrate } \\
\text { (range not defined) }\end{array}$ & & & & & & {$[138]$} \\
\hline $\begin{array}{l}\text { Isosorbide dinitrate }{ }^{\mathrm{f}} \\
\text { (range not defined) }\end{array}$ & & & & & & [139] \\
\hline
\end{tabular}


Table 1 (continued)

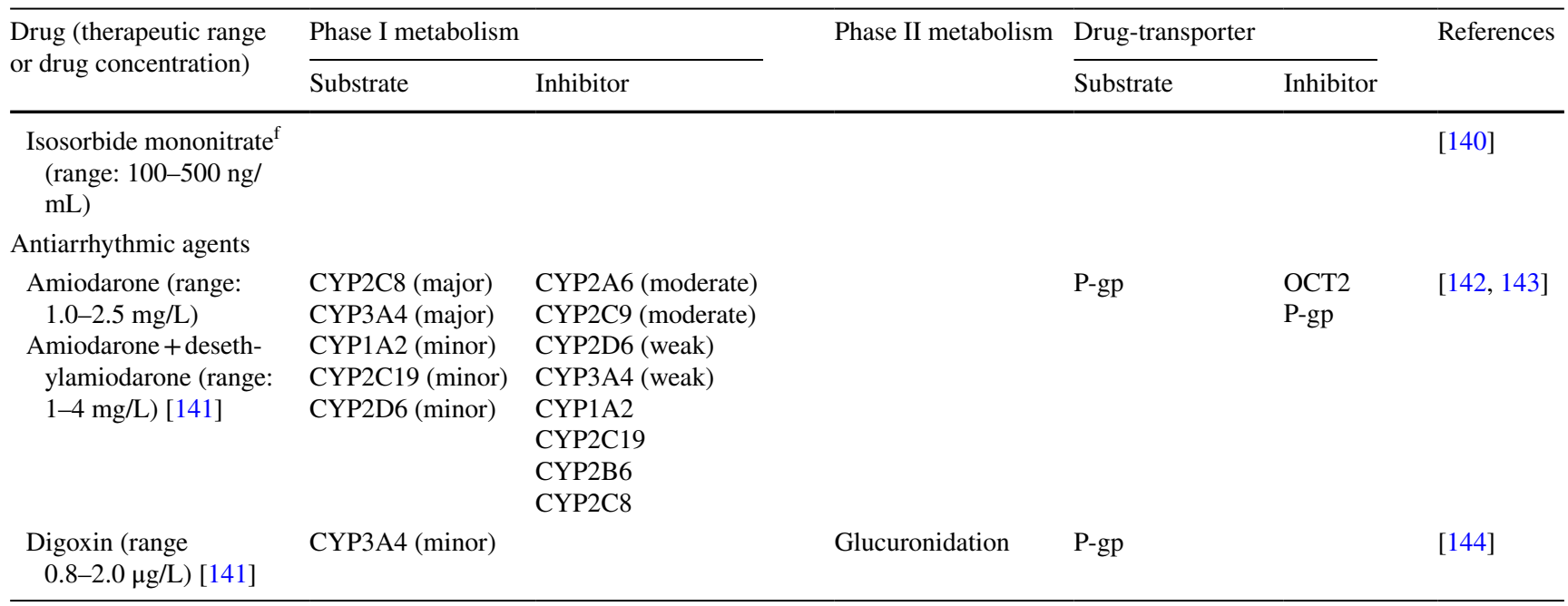

This table was created with the greatest care using the most commonly used references to obtain information about the drug metabolism and disposition and therapeutic ranges of each drug. To create this table, first we used the drug labels published by the EMA and/or US Food and Drug Administration were used and, secondly, Micromedex ${ }^{\circledR}$ (http://www.micromedexsolutions.com), KNMP Kennisbank provided by the Royal Dutch Pharmacists Association (https://kennisbank.knmp.nl), Farmacotherapeutisch Kompas provided by the Dutch National Health Care Institute (https://www.farmacotherapeutischkompas.nl), and the Lexicomp database (https://www.uptodate.com) were used. If other references were used, these appear in the table. However, this table is probably not an exhaustive list of all involved/studied drug transporters and drug-metabolizing enzymes. Drug-metabolizing enzymes and drug transporters are only presented when they are considered clinically relevant in vivo. If it is not clear if it is studied in vivo these enzymes and transporters are presented in the table

Enzyme inhibitors and inducers were defined as being strong, moderate, or weak if they changed the area under the concentration-time curve (AUC) of a substrate by 5-fold, $>2$ - to $<5$-fold, and 1.25- to $<2$-fold, respectively. Substrates were also grouped as being minor and major substrates of enzymes. These groupings were based on the clinical relevance of the potential interaction described by described by EMA [145]

$B C R P$ breast cancer resistance protein, $C Y P$ cytochrome P450, EMA European Medicines Agency, $L D L$ low-density lipoprotein, $M R P$ multidrug resistance protein, $O A T P$ organic anion transporting polypeptide, $O C T$ organic cation transport, $P$-g $p$ P-glycoprotein, $U G T$ uridine 5 '-diphosphoglucuronosyltransferase

${ }^{a}$ No involvement of drug-metabolizing enzymes and drug transporters is described in the literature

${ }^{\mathrm{b}}$ Hydrolysis

${ }^{\mathrm{c}}$ Renal clearance

${ }^{\mathrm{d}}$ Desulfation and polymerization

${ }^{\mathrm{e}}$ Oxidation by reductases

${ }^{\mathrm{f}}$ Unknown liver metabolism

described: poor, extensive, rapid, and ultra-rapid metabolizers. CYP2D6 is involved in the metabolism of, for example, metoprolol and propranolol. These polymorphisms should also be considered in respect to drug interactions. For example, in patients that are poor metabolizers of CYP2D6, using a drug that inhibits CYP2D6 is not clinically relevant, as limited metabolism of CYP2D6 takes place [15].

As already noted, the DAAs are known for DDIs in HCV treatment as these drugs are both substrates and inhibitors/ inducers of various drug-metabolizing enzymes and drug transporters (Table 2). The magnitude of the net effect of this interaction, expressed as the percentage increase of the decrease of, for example, the area under the plasma concentration-time curve(AUC) (total exposure), is important in the interpretation of drug interactions.

Another important aspect is that the magnitude of the interaction must be interpreted in light of the therapeutic range of a victim drug (Fig. 2b). One can imagine that for drugs with a narrow therapeutic range (e.g., amiodarone, digoxin), a moderate drug interaction is of bigger influence than drugs with a wide therapeutic range (the DAAs in general). For 
Table 2 Drug-metabolizing enzymes and drug transporters involved in the metabolism and distribution of the direct-acting antivirals

\begin{tabular}{|c|c|c|c|c|c|c|}
\hline \multirow[t]{2}{*}{ DAA } & \multicolumn{3}{|c|}{ Drug-metabolizing enzyme } & \multicolumn{2}{|l|}{ Drug-transporter } & \multirow[t]{2}{*}{ References } \\
\hline & Substrate & Inhibitor & Inducer & Substrate & Inhibitor & \\
\hline Daclatasvir & CYP3A4 (major) & & & $\begin{array}{l}\text { P-gp } \\
\text { OCT1 }\end{array}$ & $\begin{array}{l}\text { P-gp } \\
\text { OATP1B1/3 BCRP }\end{array}$ & {$[21,22]$} \\
\hline Grazoprevir & CYP3A & CYP3A (weak) & & $\begin{array}{l}\text { P-gp } \\
\text { OATP1B1/3 }\end{array}$ & BCRP & {$[41,42]$} \\
\hline Elbasvir & CYP3A & & & P-gp & $\begin{array}{l}\text { BCRP } \\
\text { P-gp }\end{array}$ & {$[41,42]$} \\
\hline Glecaprevir & CYP3A4 (minor) & $\begin{array}{l}\text { CYP3A4 (weak) } \\
\text { CYP1A2 (weak) } \\
\text { UGT1A1 (weak) }\end{array}$ & & $\begin{array}{l}\text { P-gp } \\
\text { BCRP } \\
\text { OATP1B1/3 }\end{array}$ & $\begin{array}{l}\text { P-gp } \\
\text { BCRP } \\
\text { OATP1B1/3 }\end{array}$ & {$[28,29]$} \\
\hline Pibrentasvir & CYP3A4 (minor) & $\begin{array}{l}\text { CYP3A4 (weak) } \\
\text { CYP1A2 (weak) } \\
\text { UGT1A1 (weak) }\end{array}$ & & $\begin{array}{l}\text { P-gp } \\
\text { BCRP }\end{array}$ & $\begin{array}{l}\text { P-gp } \\
\text { BCRP } \\
\text { OATP1B1/3 }\end{array}$ & {$[28,29]$} \\
\hline Ledipasvir & & & & $\begin{array}{l}\text { P-gp } \\
\text { BCRP }\end{array}$ & $\begin{array}{l}\text { P-gp } \\
\text { BCRP }\end{array}$ & {$[146,147]$} \\
\hline Sofosbuvir/GS-331007 & & & & $\begin{array}{l}\text { Sofosbuvir: P-gp } \\
\text { BCRP } \\
\text { GS-331007: not a sub- } \\
\text { strate of P-gp or BCRP }\end{array}$ & & {$[18,19]$} \\
\hline Paritaprevir & CYP3A4 > CYP3A5 & UGT1A1 & & $\begin{array}{l}\text { OATP1B1/3 } \\
\text { P-gp } \\
\text { BCRP }\end{array}$ & $\begin{array}{l}\text { OATP1B1/3 } \\
\text { OATP2B1 } \\
\text { BCRP }\end{array}$ & {$[23,24]$} \\
\hline Ritonavir & $\begin{array}{l}\text { CYP3A4 (major) } \\
\text { CYP2D6 }\end{array}$ & $\begin{array}{l}\text { CYP3A4 (strong) } \\
\text { CYP2D6 }\end{array}$ & $\begin{array}{l}\text { CYP2C9 } \\
\text { CYP1A2 } \\
\text { (weak) } \\
\text { CYP2C19 } \\
\quad \text { (weak) } \\
\text { CYP2B6 } \\
\text { CYP3A } \\
\text { Glucuronosyl } \\
\text { transferase }\end{array}$ & P-gp & $\begin{array}{l}\text { OATP2B1 } \\
\text { BCRP }\end{array}$ & {$[23,24]$} \\
\hline Dasabuvir & CYP2C8 CYP3A & $\begin{array}{l}\text { UGT1A1 } \\
\text { UGT1A4 } \\
\text { UGT1A6 } \\
\text { UGT2B7 }\end{array}$ & & $\begin{array}{l}\text { P-gp } \\
\text { BCRP } \\
\text { OATP } \\
\text { OCT }\end{array}$ & BCRP & {$[24,37]$} \\
\hline Ombitasvir & & UGT1A1 & & & & {$[23,24]$} \\
\hline Simeprevir & Intestinal CYP3A4 & $\begin{array}{l}\text { CYP1A2 (weak) } \\
\text { CYP3A4 (weak) }\end{array}$ & & $\begin{array}{l}\text { OATP1B1/3 } \\
\text { P-gp }\end{array}$ & $\begin{array}{l}\text { OATP1B1/3 } \\
\text { P-gp } \\
\text { BCRP }\end{array}$ & {$[40,148]$} \\
\hline Velpatasvir & $\begin{array}{l}\text { CYP2B6 } \\
\text { CYP2C8 } \\
\text { CYP3A4 }\end{array}$ & & & $\begin{array}{l}\text { P-gp } \\
\text { BCRP } \\
\text { OATP1B }\end{array}$ & $\begin{array}{l}\text { P-gp } \\
\text { BCRP } \\
\text { OATP1B1/3 } \\
\text { OATP2B1 }\end{array}$ & {$[75,149]$} \\
\hline Voxilaprevir & CYP3A4 & & & $\begin{array}{l}\text { P-gp } \\
\text { BCRP } \\
\text { OATP1B1/3 }\end{array}$ & $\begin{array}{l}\text { P-gp } \\
\text { BCRP } \\
\text { OATP1B1/3 OATP2B1 }\end{array}$ & {$[61,62]$} \\
\hline
\end{tabular}

This table was created with the greatest care using the most commonly used references to obtain information about the drug metabolism and disposition and therapeutic ranges of each drug. To create this table, first we used the drug labels published by the EMA and/or US Food and Drug Administration were used and, secondly, Micromedex ${ }^{\circledR}$ (http://www.micromedexsolutions.com), KNMP Kennisbank provided by the Royal Dutch Pharmacists Association (https://kennisbank.knmp.nl), Farmacotherapeutisch Kompas provided by the Dutch National Health Care Institute (https://www.farmacotherapeutischkompas.nl), and the Lexicomp database (https://www.uptodate.com) were used. If other references were used, these appear in the table. However, this table is probably not an exhaustive list of all involved/studied drug transporters and drug-metabolizing enzymes. Drug-metabolizing enzymes and drug transporters are only presented when they are considered clinically relevant in vivo. Any enzymes and transporters for which it is not clear if they have not been studied in vivo are not presented in the table

Enzyme inhibitors and inducers were defined as being strong, moderate, or weak if they changed the area under the concentration-time curve (AUC) of a substrate by 5 -fold, $>2$ - to $<5$-fold, and 1.25- to $<2$-fold, respectively. Substrates were also grouped as being minor and major substrates of enzymes. These groupings were based on the clinical relevance of the potential interaction described by described by EMA [145]

$B C R P$ breast cancer resistance protein, $C Y P$ cytochrome P450, DAA direct-acting antiviral, EMA European Medicines Agency, MRP multidrug resistance protein, $O A T P$ organic anion transporting polypeptide, $O C T$ organic cation transport, $P$-gp P-glycoprotein, $U G T$ uridine 5 '-diphosphoglucuronosyltransferase 


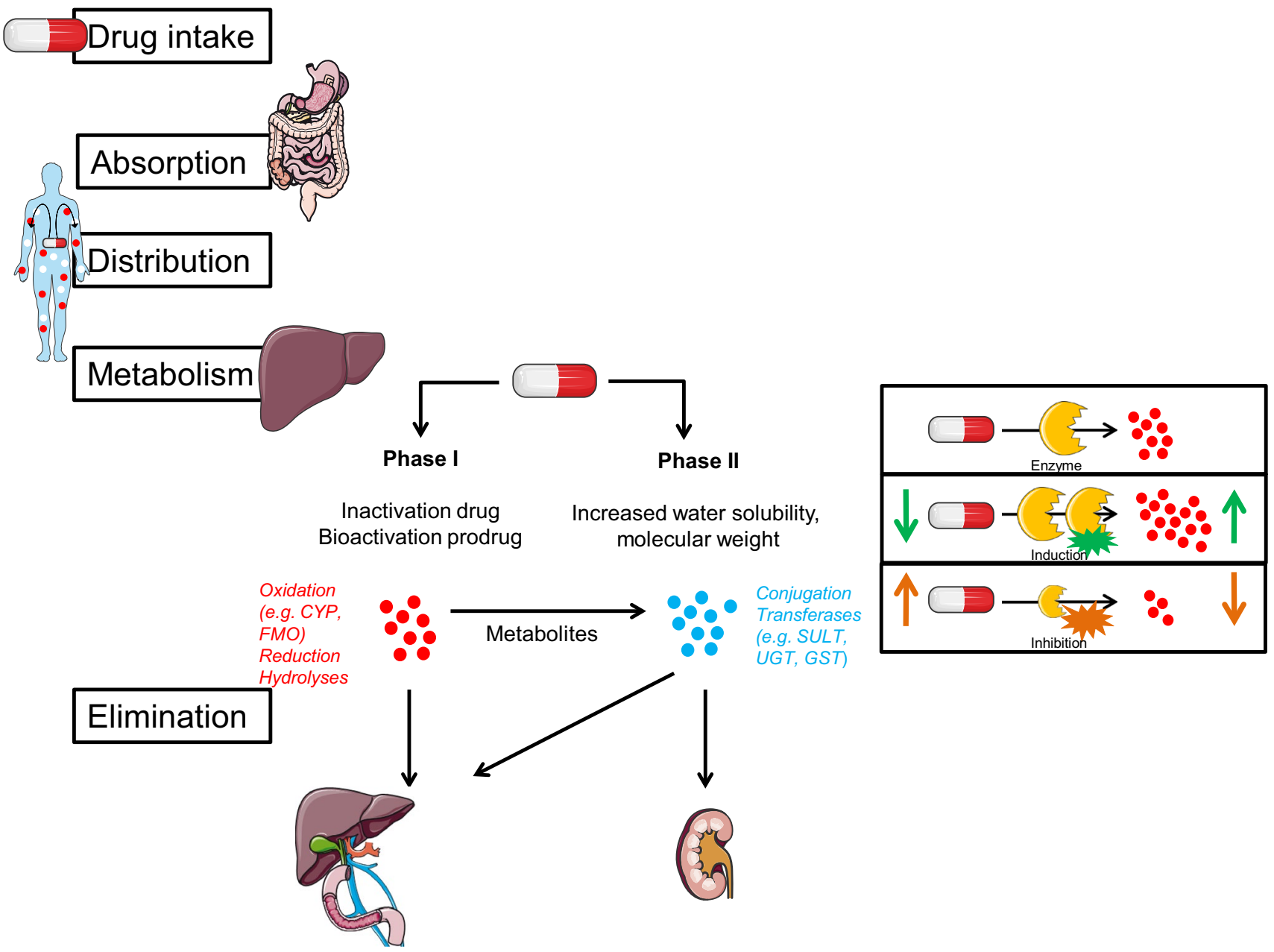

Fig. 1 Overview of phase I and phase II drug-metabolism. CYP cytochrome P450, FMO flavin-containing mono-oxygenase, GST glutathione S-transferases, SULT sulfotransferase, UGT uridine 5'-diphospho-glucuronosyltransferase

Fig. 2 General overview of the pharmacokinetic-pharmacodynamic relationship of a drug: a therapeutic range of a drug versus the pharmacodynamic effect; and $\mathbf{b}$ therapeutic range of a drug using a pharmacokinetic curve, combined with an example of the influence of a drug interaction. $D D I$ drugdrug interaction
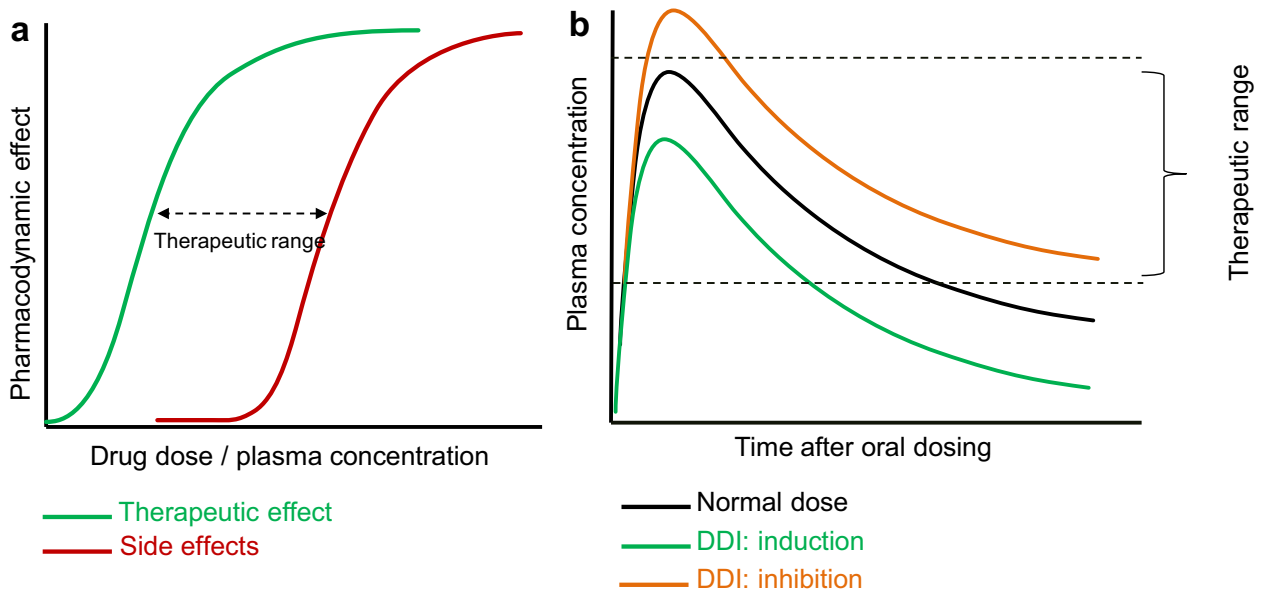
Fig. 3 Overview of various pharmacokinetic mechanisms of drug-drug interactions. $G I$ gastrointestinal. Modified from $[151,152]$

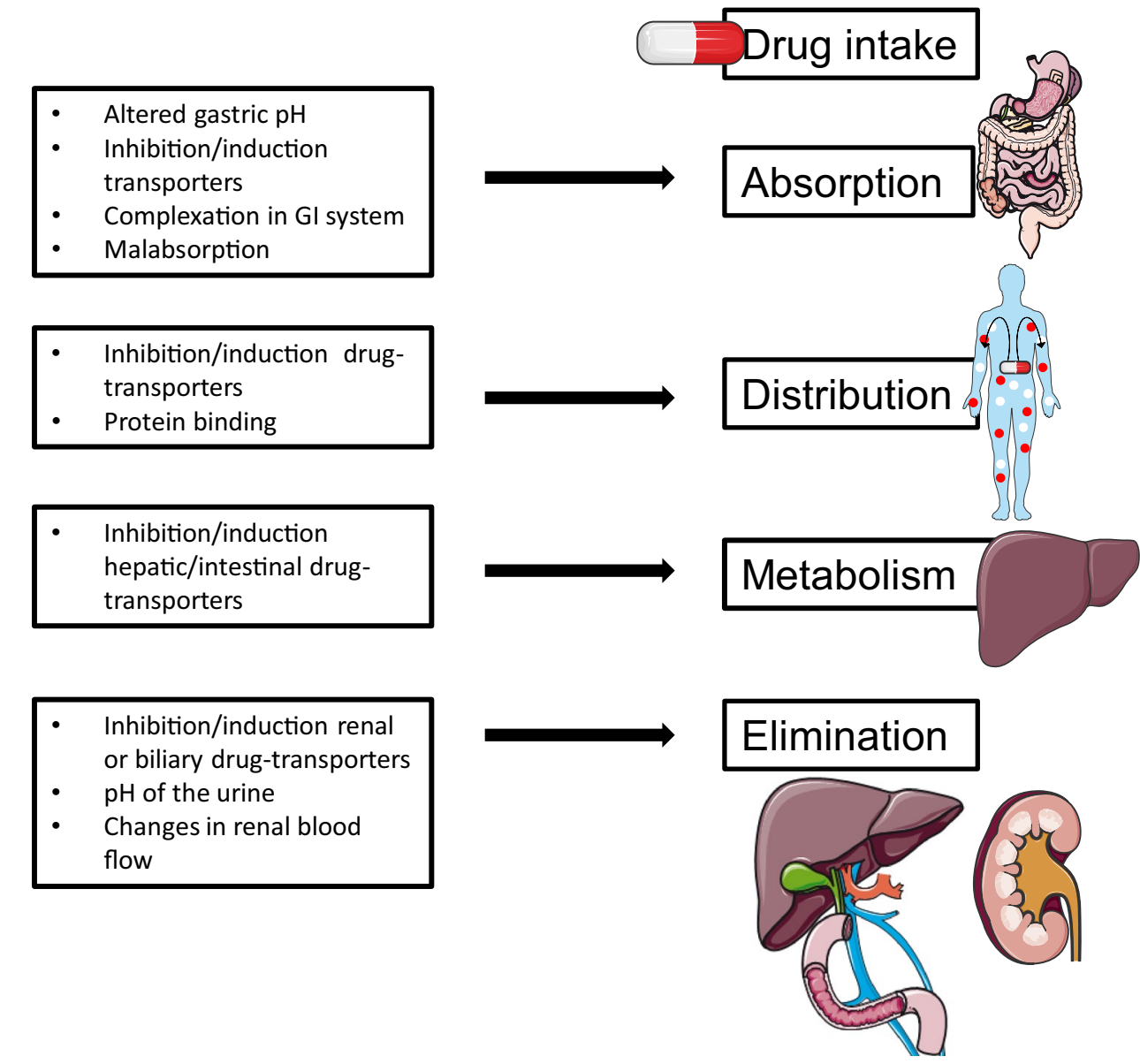

most CVDs discussed in this review, no therapeutic range is defined (Table 1). These drugs are usually administered on clinical response, for example by measuring blood pressure or cholesterol.

\section{Drug Interactions Between Cardiovascular Drugs (CVDs) and Direct-Acting Antivirals (DAAs)}

In this section we discuss the different classes of CVDs and the factors that make CVDs victims or perpetrators of drug interactions. We explain the mechanisms of the (proposed) drug interactions and discuss the clinical relevance.

Table 1 provides an overview of the selected CVDs and their influence on drug-metabolizing enzymes and drug transporters, as well as the enzymes and drug transporters that are responsible for their metabolism or transport. The same information is given for the DAAs in Table 2.

Table 3 presents all known drug interactions that have been studied in vivo between DAAs and CVDs. The magnitude of the drug interaction is presented as the geometric mean ratio (GMR) with $90 \%$ confidence intervals of the
AUC, maximum (peak) plasma concentration $\left(C_{\max }\right)$, and minimum (trough) plasma concentration $\left(C_{\min }\right)$.

We also make predictions for those cases where no in vivo drug interaction studies were found. In the following sections we explain, based on studies in humans and on predictions, which combinations of CVDs and DAAs can be safely used, how DDIs can be managed, and which drugs are contraindicated when using DAAs. Table 4 describes the clinically relevant DDIs and the recommended management for these.

\section{1 $\beta$-Blocking Agents}

\subsubsection{CVDs as Perpetrators}

Based on the metabolism of bisoprolol, carvedilol, and labetalol, we believe there are DDIs with DAAs (Table 1). For example, carvedilol is a substrate of, among others, CYP2C19, CYP2D6, and P-glycoprotein (P-gp) and the metabolites are glucuronidated. Therefore, a DDI is expected with all the DAAs, except sofosbuvir alone. As carvedilol also inhibits P-gp, the plasma concentrations of daclatasvir, glecaprevir/pibrentasvir, simeprevir, and ledipasvir may rise when combined with carvedilol [16]. This makes monitoring 


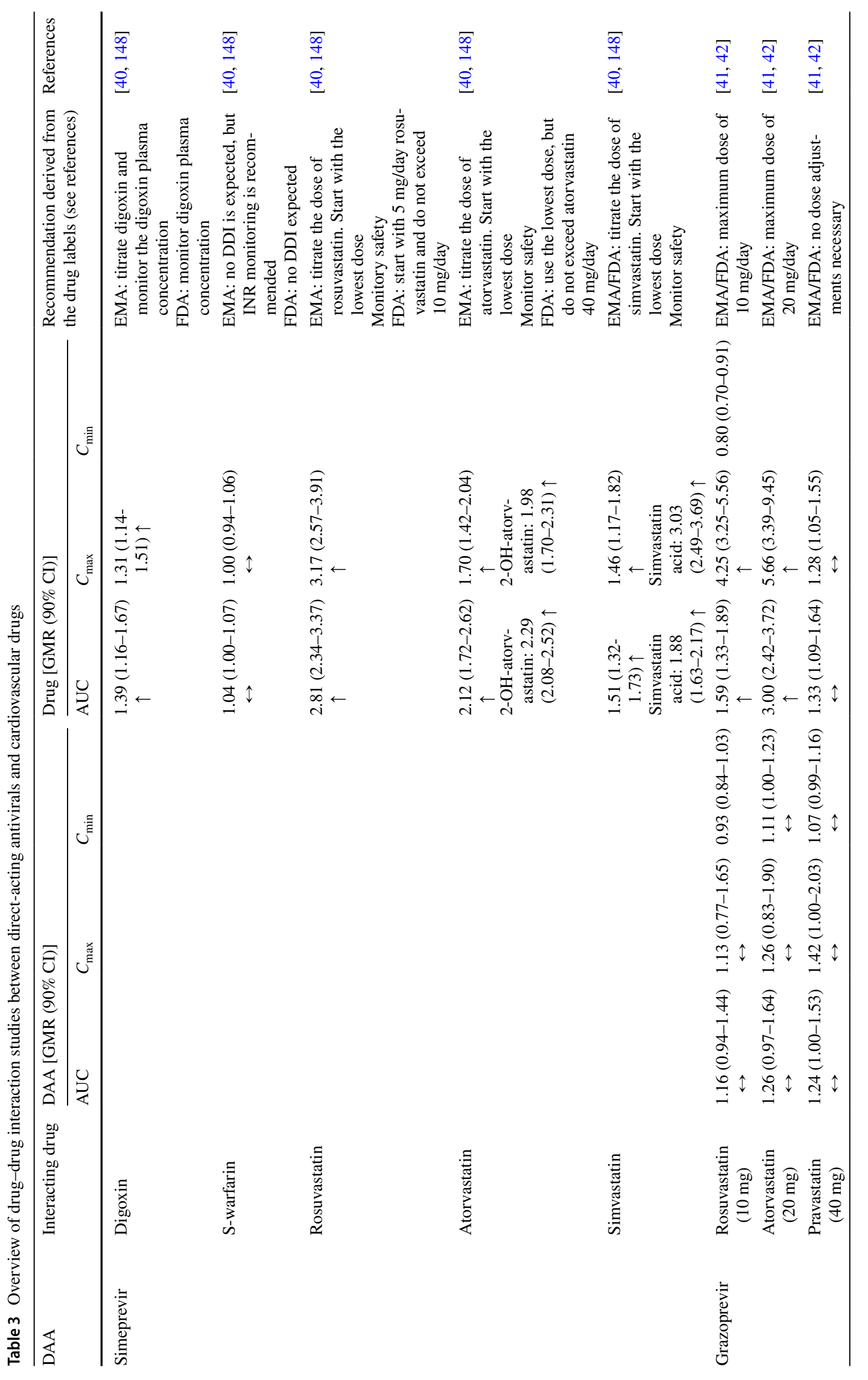




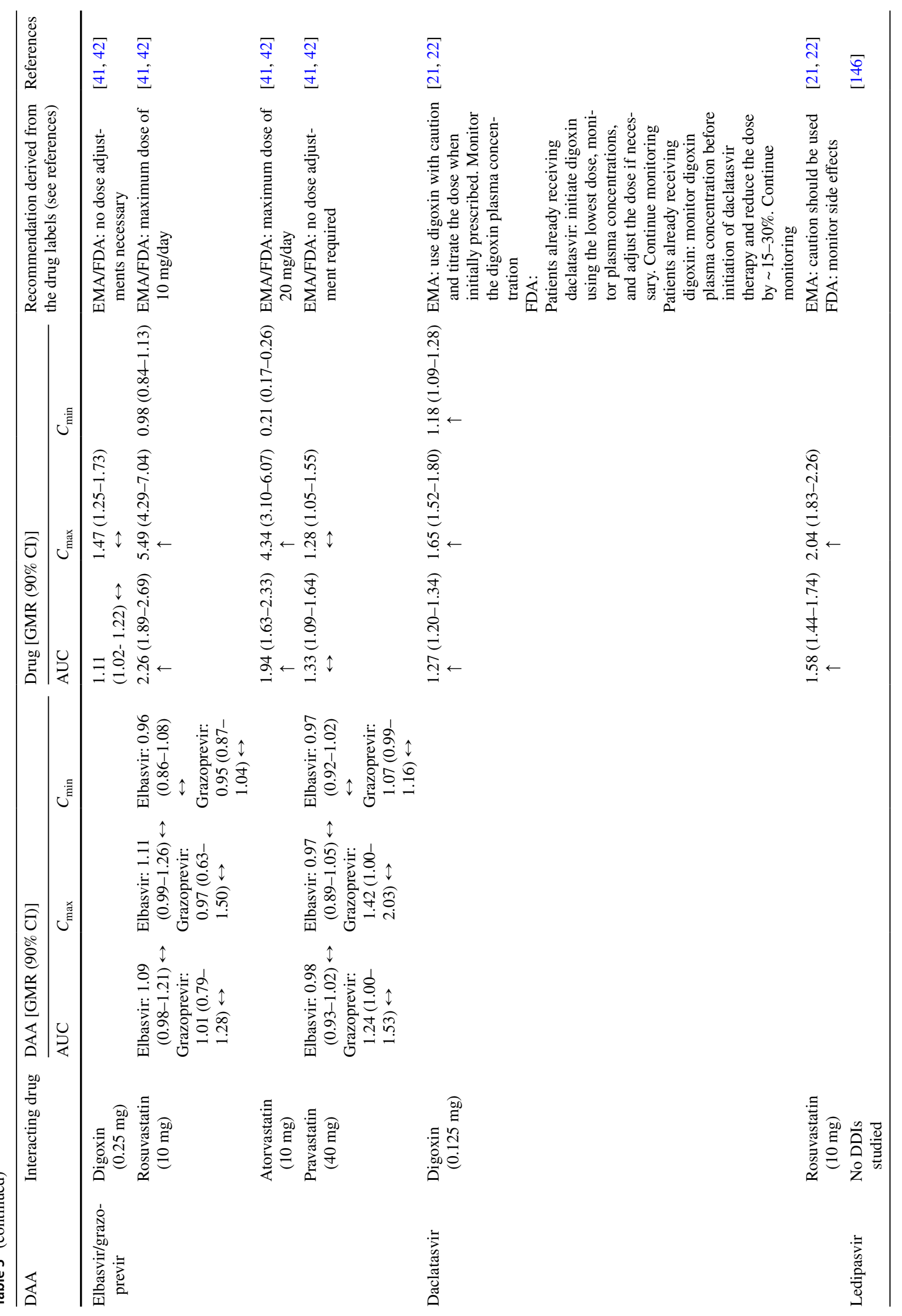




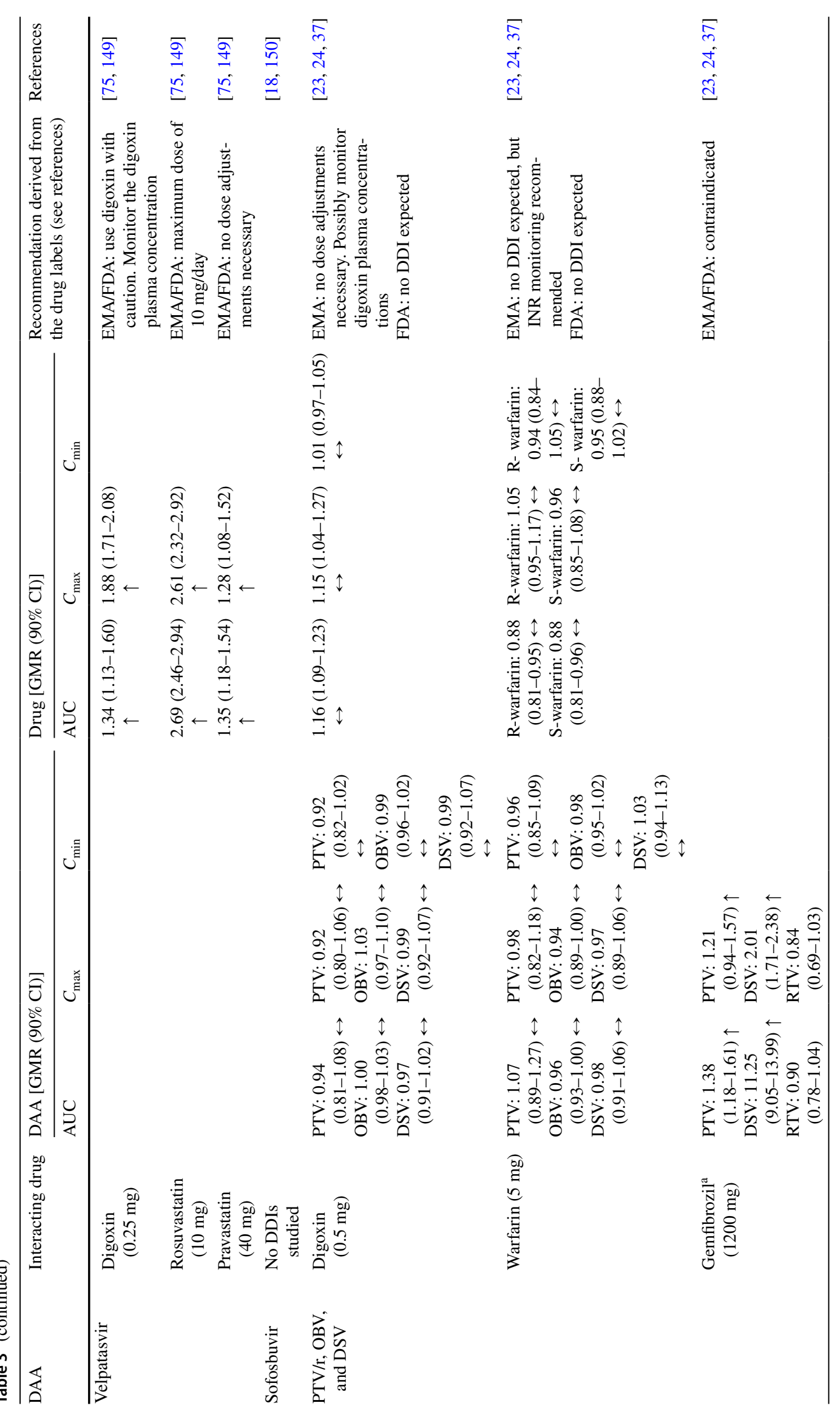




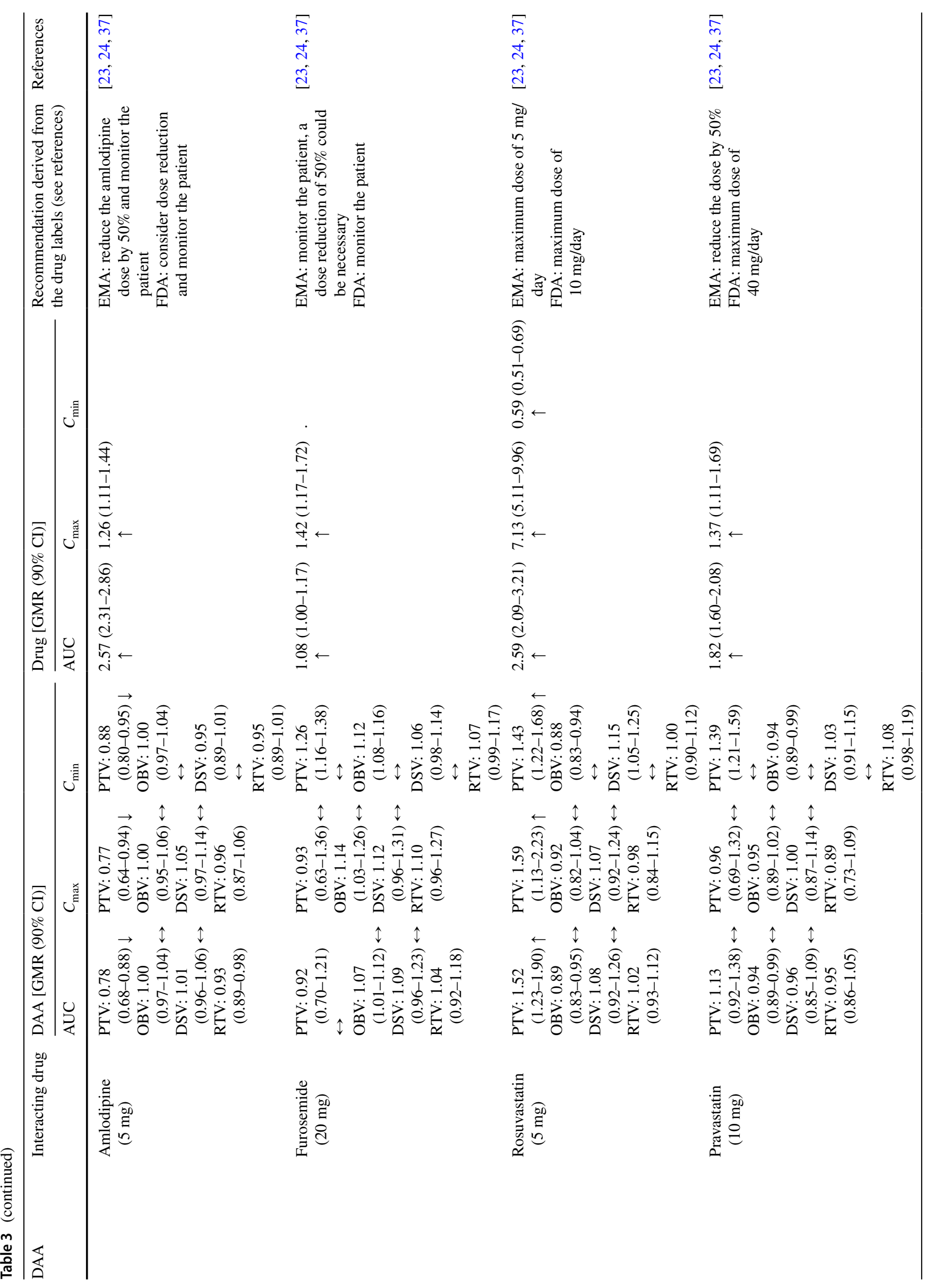




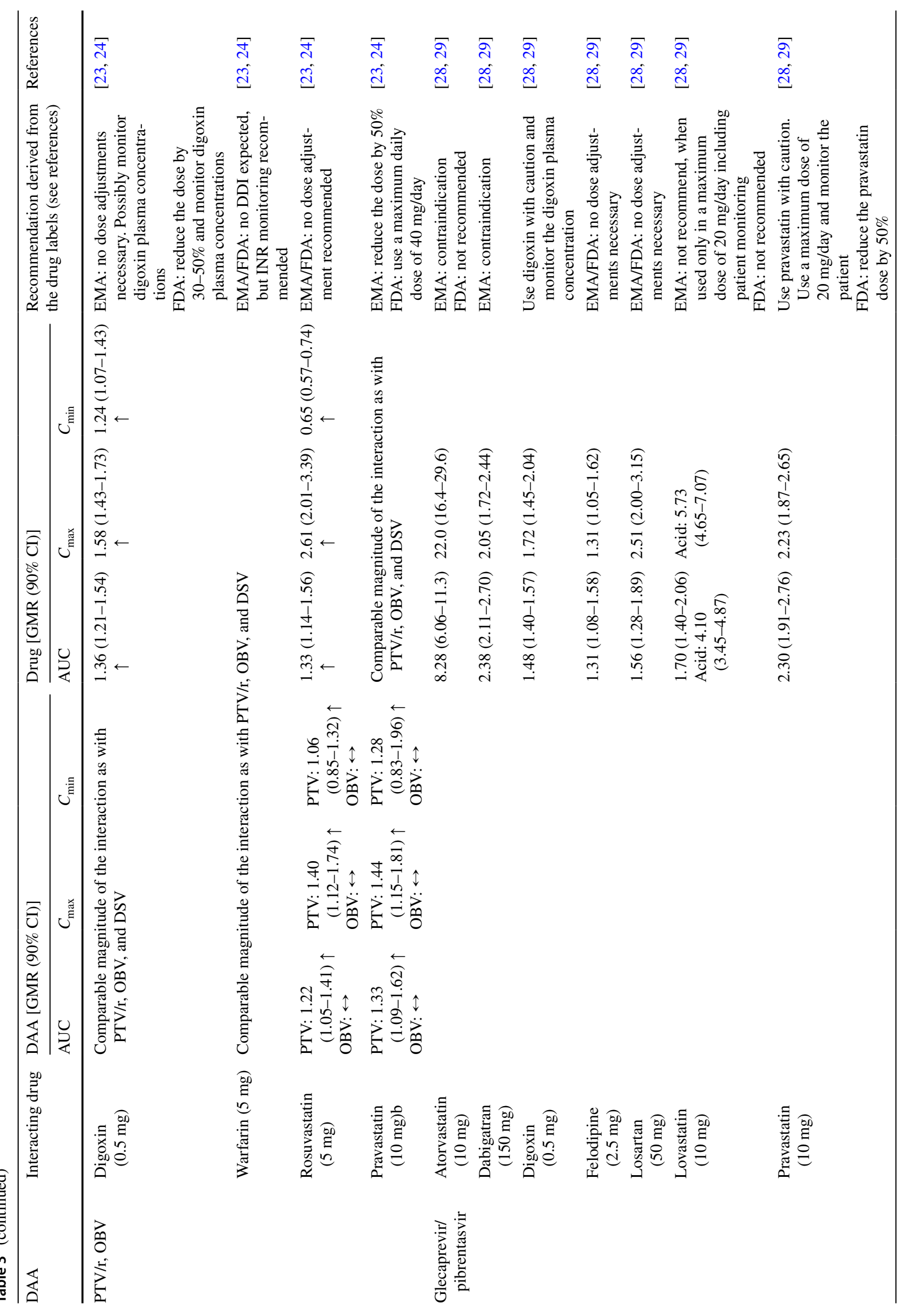




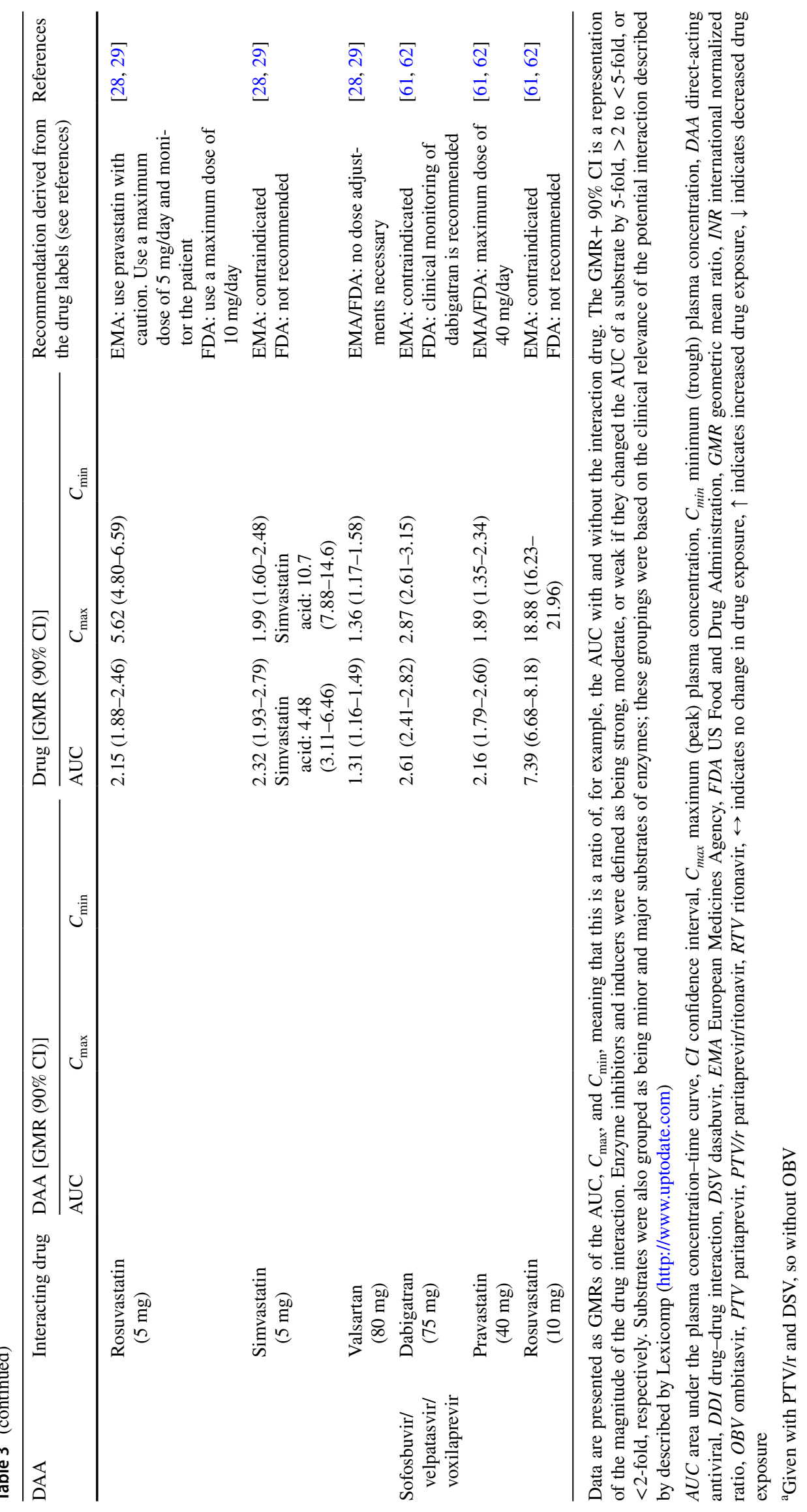


Table 4 Expected drug-drug interactions between direct-acting antivirals and cardiovascular medication

\begin{tabular}{|c|c|c|c|}
\hline Drug & DAA & Management & Contraindicated regimen \\
\hline \multicolumn{4}{|c|}{$\beta$-Blocking agents } \\
\hline Bisoprolol & SIM, PrO, PrOD & $\begin{array}{l}\text { Monitoring patient and decreased dose } \\
\text { could be necessary (PrO, PrOD) }\end{array}$ & \\
\hline Carvedilol & $\begin{array}{l}\text { DAC, G/P, LED/SOF, PrO, PrOD, SIM, } \\
\text { SOF/VEL, SOF/VEL/VOX }\end{array}$ & $\begin{array}{l}\text { Monitor toxicity of both DAA (DAC, } \\
\text { G/P, SIM, LED) and carvedilol }\end{array}$ & \\
\hline Labetalol & PrO, PrOD & Monitor side effects & \\
\hline \multicolumn{4}{|l|}{ ACE inhibitor } \\
\hline Enalapril & G/P, PrO, PrOD, SOF/VEL/VOX & $\begin{array}{l}\text { Monitoring of the patient and a } \\
\text { decreased dose could be necessary }\end{array}$ & \\
\hline \multicolumn{4}{|c|}{ Angiotensin II antagonists and renin inhibitors } \\
\hline Irbesartan & $\mathrm{G} / \mathrm{P}, \mathrm{PrO}, \mathrm{PrOD}$ & $\begin{array}{l}\text { Monitoring of the patient. A decreased } \\
\text { dose could be necessary (PrO, PrOD) }\end{array}$ & \\
\hline Olmesartan & DAC, G/P, PrO, PrOD, SOF/VEL/VOX & $\begin{array}{l}\text { Monitoring of the patient and a } \\
\text { decreased initial dose of } 10 \mathrm{mg} / \text { day }\end{array}$ & \\
\hline Telmisartan & G/P, PrO, PrOD & $\begin{array}{l}\text { Monitoring of the patient. A decreased } \\
\text { dose could be necessary }\end{array}$ & \\
\hline Valsartan & $\mathrm{PrO}, \mathrm{PrOD}, \mathrm{SOF} / \mathrm{VEL} / \mathrm{VOX}$ & $\begin{array}{l}\text { Monitoring of the patient. A decreased } \\
\text { dose could be necessary }\end{array}$ & \\
\hline Aliskiren & DAC, LED/SOF, SIM & Be careful. Monitor for hypotension & G/P, PrO, PrOD \\
\hline \multicolumn{4}{|l|}{ Diuretics } \\
\hline Eplerenone & EBR/GZR, G/P, SIM & $\begin{array}{l}\text { Monitor the patient and start with a } \\
\text { lower dose }\end{array}$ & PrO, PrOD \\
\hline Furosemide & $\mathrm{PrO}, \mathrm{PrOD}^{\mathrm{a}}$ & $\begin{array}{l}\text { Monitor the patient, a reduction of } 50 \% \\
\text { could be necessary }\end{array}$ & \\
\hline \multicolumn{4}{|c|}{ Calcium channel blockers } \\
\hline Amlodipine & DAC, LED/SOF, PrO, PrOD ${ }^{\mathrm{a}}$, SIM & $\begin{array}{l}\text { Monitor the heart rate and blood pres- } \\
\text { sure of the patient. Reduce the dose by } \\
50 \% \text { (PrO, PrOD) }\end{array}$ & \\
\hline Barnidipine & PrO, PrOD, SIM, PrO, PrOD, SIM & $\begin{array}{l}\text { Monitor the patient heart rate and blood } \\
\text { pressure }\end{array}$ & \\
\hline Diltiazem & $\begin{array}{l}\text { DAC, G/P, LED/SOF, PrO, PrOD, SIM, } \\
\text { SOF/VEL, SOF/VEL/VOX }\end{array}$ & $\begin{array}{l}\text { Monitor the patient heart rate and blood } \\
\text { pressure }\end{array}$ & \\
\hline Felodipine & EBR/GZR, PrO, PrOD, SIM & $\begin{array}{l}\text { Monitor the patient heart rate and blood } \\
\text { pressure. }\end{array}$ & \\
\hline Lercanidipine & DAC, SIM & $\begin{array}{l}\text { Monitor the patient heart rate and blood } \\
\text { pressure }\end{array}$ & PrO, PrOD \\
\hline Nicardipine & $\begin{array}{l}\text { DAC, G/P, LED/SOF, PrO, PrOD, SIM, } \\
\text { SOF/VEL, SOF/VEL/VOX }\end{array}$ & $\begin{array}{l}\text { Monitor the patient heart rate and blood } \\
\text { pressure }\end{array}$ & \\
\hline Nifedipine & PrO, PrOD, SIM & $\begin{array}{l}\text { Monitor the patient heart rate and blood } \\
\text { pressure }\end{array}$ & \\
\hline Verapamil & $\begin{array}{l}\text { DAC, G/P, LED/SOF, PrO, PrOD, SIM, } \\
\text { SOF/VEL, SOF/VEL/VOX }\end{array}$ & $\begin{array}{l}\text { Monitor the patient heart rate and blood } \\
\text { pressure }\end{array}$ & \\
\hline \multicolumn{4}{|c|}{ Statins and ezetimibe } \\
\hline Atorvastatin & $\begin{array}{l}\text { DAC, EBR/GZR }{ }^{\mathrm{a}}, \mathrm{LED} / \mathrm{SOF}, \mathrm{SIM}^{\mathrm{a}} \text {, } \\
\text { SOF/VEL }\end{array}$ & $\begin{array}{l}\text { Discontinue statin if possible or start } \\
\text { statin later } \\
\text { Monitor safety and start with the lowest } \\
\text { dose. Maximum } 40 \mathrm{mg} / \text { day (SIM) } \\
\text { Maximum } 20 \mathrm{mg} / \text { day (GZR) }\end{array}$ & G/Pa, PrO, PrOD, SOF/VEL/VOX \\
\hline Ezetimibe & $\begin{array}{l}\text { DAC, SIM, G/P, PrO, PrOD, SOF/VEL/ } \\
\text { VOX }\end{array}$ & $\begin{array}{l}\text { Monitor the patient and start with the } \\
\text { lowest dose }\end{array}$ & \\
\hline Fluvastatin & $\begin{array}{l}\text { DAC, EBR/GZR, G/P, LED/SOF, PrO, } \\
\text { PrOD, SOF/VEL }\end{array}$ & $\begin{array}{l}\text { Discontinue statin if possible or start } \\
\text { statin later }\end{array}$ & SOF/VEL/VOX \\
\hline
\end{tabular}


Table 4 (continued)

\begin{tabular}{|c|c|c|c|}
\hline Drug & DAA & Management & Contraindicated regimen \\
\hline Lovastatin & $\begin{array}{l}\text { DAC, EBR/GZR, LED/SOF, SIM, SOF/ } \\
\text { VEL }\end{array}$ & $\begin{array}{l}\text { Discontinue statin if possible or start } \\
\text { statin later } \\
\text { Monitor the patient and a maximum } \\
\text { daily dose of } 20 \mathrm{mg} / \text { day }\end{array}$ & $\mathrm{G} / \mathrm{P}^{\mathrm{a}}, \mathrm{PrO}, \mathrm{PrOD}, \mathrm{SOF} / \mathrm{VEL} / \mathrm{VOX}$ \\
\hline Pravastatin & $\begin{array}{l}\text { DAC, LED/SOF, G/P }{ }^{\mathrm{a}}, \mathrm{PrO}^{\mathrm{a}}, \mathrm{PrOD}^{\mathrm{a}} \text {, } \\
\text { SIM, SOF/VEL/VOX }\end{array}$ & $\begin{array}{l}\text { Discontinue statin if possible or start } \\
\text { statin later } \\
\text { Reduce the dose by } 50 \% \text { or use a maxi- } \\
\text { mum dose of } 40 \mathrm{mg} / \text { day }(\mathrm{PrOD}, \mathrm{SOF} / \\
\text { VEL/VOX) or } 20 \mathrm{mg} / \text { day }(\mathrm{G} / \mathrm{P})\end{array}$ & \\
\hline Rosuvastatin & $\begin{array}{l}\mathrm{DAC}^{\mathrm{a}}, \mathrm{EBR} / \mathrm{GZR}^{\mathrm{a}}, \mathrm{G} / \mathrm{P}^{\mathrm{a}}, \operatorname{PrO}, \mathrm{PrOD}^{\mathrm{a}}, \\
\mathrm{SIM}^{\mathrm{a}}, \mathrm{SOF} / \mathrm{VEL}^{\mathrm{a}}\end{array}$ & $\begin{array}{l}\text { Discontinue statin if possible or start } \\
\text { statin later } \\
\text { Monitor safety and start with the lowest } \\
\text { dose } \\
\text { Maximum } 10 \mathrm{mg} / \text { day (GZR, VEL, } \\
\text { PrOD, G/P) } \\
\text { Be careful (DAC) }\end{array}$ & LED/SOF, SOF/VEL/VOX ${ }^{\mathrm{a}}$ \\
\hline Simvastatin & $\begin{array}{l}\text { DAC, EBR/GZR, LED/SOF, SIM }{ }^{\mathrm{a}} \text {, } \\
\text { SOF/VEL }\end{array}$ & $\begin{array}{l}\text { Discontinue statin if possible or start } \\
\text { statin later } \\
\text { Monitor safety and start with the lowest } \\
\text { dose }\end{array}$ & $\mathrm{PrO}, \mathrm{PrOD}, \mathrm{G} / \mathrm{P}^{\mathrm{a}}$, SOF/VEL/VOX \\
\hline Ciprofibrate & PrO, PrOD & Monitor side effects, use other fibrate & \\
\hline Gemfibrozil & EBR/GZR, G/P, SIM, PrO & $\begin{array}{l}\text { EBR/GZR, G/P, SIM concentrations } \\
\text { may rise, monitor close for side effects } \\
\text { (e.g., ALT by EBR/GZR) or use other } \\
\text { DAA } \\
\text { Gemfibrozil concentrations might } \\
\text { decrease. Monitor lipid profile during } \\
\text { PrO treatment }\end{array}$ & $\operatorname{PrOD}^{\mathrm{a}}$ \\
\hline \multicolumn{4}{|c|}{ Platelet aggregation inhibitors } \\
\hline Dipyridamole & PrO, PrOD & $\begin{array}{l}\text { Monitor side effects, no a priori dose } \\
\text { adjustment required }\end{array}$ & \\
\hline Clopidogrel (prodrug) & PrO, PrOD, SIM & $\begin{array}{l}\text { Use an alternative DAA regimen or } \\
\text { platelet aggregation inhibitor }\end{array}$ & \\
\hline Prasugrel (prodrug) & PrO, PrOD & $\begin{array}{l}\text { Use an alternative DAA regimen or } \\
\text { platelet aggregation inhibitor }\end{array}$ & \\
\hline Ticagrelor (prodrug) & $\begin{array}{l}\text { DAC, EBR/GZR, G/P, LED/SOF, SIM, } \\
\text { SOF/VEL, SOF/VEL/VOX }\end{array}$ & Monitor the patient & PrO, PrOD \\
\hline \multicolumn{4}{|l|}{ Vitamin $\mathrm{K}$ antagonists } \\
\hline Acenocoumarol & G/P, PrO, PrOD & Monitor INR & \\
\hline Phenprocoumon & $\begin{array}{l}\text { EBR/GZR, G/P, LED/SOF, PrO, PrOD, } \\
\text { SIM, SOF/VEL/VOX }\end{array}$ & Monitor INR & \\
\hline Warfarin & $\begin{array}{l}\text { DAC, EBR/GZR, G/P, LED/SOF, PrO, } \\
\text { PrOD }{ }^{\mathrm{a}}, \mathrm{SIM}^{\mathrm{a}}, \mathrm{SOF} / \mathrm{VEL}, \mathrm{SOF} / \mathrm{VEL} / \\
\text { VOX }\end{array}$ & Monitor INR & \\
\hline \multicolumn{4}{|l|}{ Direct factor Xa inhibitors } \\
\hline Apixaban & $\begin{array}{l}\text { DAC, EBR/GZR, G/P, LED/SOF, SIM, } \\
\text { SOF/VEL, SOF/VEL/VOX }\end{array}$ & $\begin{array}{l}\text { Close monitoring of side effects (bleed- } \\
\text { ing and anemia) }\end{array}$ & PrO, PrOD \\
\hline Dabigatran & $\begin{array}{l}\text { DAC, EBR/GZR, LED/SOF, PrO, } \\
\text { PrOD, SIM, SOF/VEL }\end{array}$ & $\begin{array}{l}\text { Be careful. Close monitoring of side } \\
\text { effects (bleeding and anemia) }\end{array}$ & $\mathrm{G} / \mathrm{P}^{\mathrm{a}}, \mathrm{SOF} / \mathrm{VEL} / \mathrm{VOX}^{\mathrm{a}}$ \\
\hline Edoxaban & $\begin{array}{l}\text { DAC, EBR/GZR, G/P, LED/SOF, PrO, } \\
\text { PrOD, SIM, SOF/VEL }\end{array}$ & $\begin{array}{l}\text { Be careful. Close monitoring of side } \\
\text { effects (bleeding and anemia) } \\
\text { Consider a reduced dose of } 30 \mathrm{mg}(\mathrm{PrO} \text {, } \\
\text { PrOD, G/P) }\end{array}$ & SOF/VEL/VOX \\
\hline Rivaroxaban & $\begin{array}{l}\text { DAC, EBR/GZR, G/P, LED/SOF, SIM, } \\
\text { SOF/VEL, SOF/VEL/VOX }\end{array}$ & $\begin{array}{l}\text { Close monitoring of side effects (bleed- } \\
\text { ing and anemia) }\end{array}$ & PrO, PrOD \\
\hline
\end{tabular}


Table 4 (continued)

\begin{tabular}{|c|c|c|c|}
\hline Drug & DAA & Management & Contraindicated regimen \\
\hline \multicolumn{4}{|c|}{ Antiarrhythmic agents } \\
\hline Amiodarone & EBR/GZR, G/P, SIM & $\begin{array}{l}\text { Close monitoring of side effects and } \\
\text { plasma concentrations of amiodarone }\end{array}$ & $\begin{array}{l}\text { DAC, LED/SOF, PrO, PrOD, } \\
\text { SOF, SOF/VEL, SOF/VEL/ } \\
\text { VOX }\end{array}$ \\
\hline Digoxin & $\begin{array}{l}\mathrm{DAC}^{\mathrm{a}}, \mathrm{EBR} / \mathrm{GZR}^{\mathrm{a}}, \mathrm{G} / \mathrm{P}^{\mathrm{a}}, \mathrm{LED} / \mathrm{SOF}, \\
\mathrm{SIM}^{\mathrm{a}}, \mathrm{PrO}^{\mathrm{a}}, \mathrm{PrOD}^{\mathrm{a}}, \mathrm{SOF}^{\mathrm{b}}, \mathrm{SEL} / \mathrm{SOF} / \\
\mathrm{VEL}^{\mathrm{b}} / \mathrm{VOX}^{\mathrm{b}}\end{array}$ & $\begin{array}{l}\text { Monitor plasma concentration and start } \\
\text { with the lowest dose }\end{array}$ & \\
\hline
\end{tabular}

Suggestions are made based on in vivo metabolism and drug disposition in Tables 1 and 2. In addition, the recommendations in the drug labels of the EMA and FDA are followed

The following drugs do not have a drug-drug interaction with the DAAs and are therefore not mentioned in the table: atenolol, metoprolol, nebivolol, propranolol, sotalol, captropril, fosinopril, lisinopril, perindopril, quinapril, ramipril, candesartan, losartan, amiloride, bumetanide, chlorothiazide, chlortalidone, hydrochlorothiazide, indapamide, spironolactone, triamterene, bezafibrate, fenofibrate, acetylsalicylic acid, carbasalate calcium, dalteparin, enoxaparin, heparin, nadroparin, fondaparinux, glyceryl trinitrate, isosorbide dinitrate, and isosorbide mononitrate

$A L T$ alanine transaminase, $D A A$ direct-acting antiviral, $D A C$ daclatasvir, EBR/GZR elbasvir/grazoprevir, EMA European Medicines Agency, FDA US Food and Drug Administration, G/P glecaprevir/pibrentasvir, GMR geometric mean ratio, INR international normalized ratio, LED/ SOF ledipasvir/sofosbuvir, $\mathrm{PrO}$ paritaprevir/ritonavir, ombitasvir, $\mathrm{PrOD}$ paritaprevir/ritonavir, ombitasvir, dasabuvir, PTV paritaprevir, SIM simeprevir, SOF/VEL/VOX sofosbuvir/velpatasvir/voxilaprevir, SOF/VEL sofosbuvir/velpatasvir

${ }^{a}$ Drug-drug interactions are studied in vivo; see Table 3

${ }^{\mathrm{b}}$ The interaction with digoxin is only studied with velpatasvir, so without sofosbuvir or voxilaprevir

of DAA toxicity advisable, especially for the protease inhibitors simeprevir, glecaprevir, and paritaprevir as, for example, (severe) skin reactions might occur. Boglione and colleagues [17] recently showed that these skin reactions were related to the simeprevir plasma concentration. Therefore, especially for simeprevir, these kinds of interactions could cause extra toxicity [17].

Sofosbuvir is also a P-gp substrate; however, it is rapidly metabolized and its primary metabolite GS-331007 is not a substrate of P-gp $[18,19]$. So, we expect that carvedilol P-gp inhibition does not influence the toxicity profile of sofosbuvir and its metabolites.

\subsubsection{CVDs as Victims}

The drug interaction between metoprolol and daclatasvir/asunaprevir/beclabuvir has been studied in vivo [20] (Table 3); however, this regimen is not licensed in Europe and the USA. Garimella and colleagues [20] showed that asunaprevir affected the metoprolol plasma concentration as it is a moderate inhibitor of CYP2D6. In vitro experiments have shown that daclatasvir is not an inhibitor of CYP2D6 [20-22].

PrOD is a mild inhibitor of CYP2D6, so there is a theoretical interaction between CYP2D6 substrates, such as metoprolol and propranolol, with this combination. We recommend care be taken in combining paritaprevir/ritonavir, ombitastir with or without dasabuvir PrO(D) with CYP2D6 substrates with narrow therapeutic ranges. This is based on the drug interaction study between PrOD and duloxetine (CYP2D6/ CYP1A2 substrate), which was performed to study CYP2D6 inhibition and CY1A2 induction by ritonavir. Duloxetine was not influenced by PrOD [23-25]. However, it can be argued that CYP2D6 inhibition was mitigated by CYP1A2 induction [26]. This should be taken into consideration when PrOD is combined with other CYP2D6 substrates, especially those with narrow therapeutic ranges (which is not the case for metoprolol and propranolol). This should also be taken into account in patients with known CYP2D6 phenotypic polymorphisms. In patients that are poor metabolizers of CYP2D6, this interaction is not relevant. However, in patients with rapid or extra-rapid metabolism, the interaction could be relevant as the metoprolol or propanol concentrations could increase compared with those without the DDI.

\subsection{ACE Inhibitors}

\subsubsection{CVDs as Victims}

No DDIs studies were found regarding ACE inhibitors and DAAs. The only clinical relevant DDI that we predict is with enalapril, a substrate of organic anion transporting polypeptide (OATP). OATP is inhibited by almost all DAAs, such as daclatasvir, velpatasvir, and $\mathrm{PrO}(\mathrm{D})$ (Table 4) [27].

We do not expect a clinically relevant DDI between captopril (CYP2D6 substrate) and $\operatorname{PrO}(\mathrm{D})$ because captopril does not have a narrow therapeutic range [23]. 


\subsection{Angiotensin II Antagonists and Renin Inhibitors}

\subsubsection{CVDs as Victims}

Losartan and valsartan (OATP substrates) have both been studied with glecaprevir/pibrentasvir. The valsartan AUC and $C_{\max }$ increased by 31 and $36 \%$, respectively, due to OATP inhibition by glecaprevir. Comparably, the losartan AUC and $C_{\max }$ increased by 56 and $151 \%$, respectively, when combined $[28,29]$. The FDA label states that these DDIs are not clinically relevant and that no dose adjustments are necessary when these drugs are combined. Irbesartan, olmesartan, and telmisartan are also substrates of OATP and therefore comparable DDIs are expected. This is probably a group effect for all angiotensin II antagonists [30, 31]. Therefore, these angiotensin II antagonists could have DDIs with DAAs that influence these OATPs, such as daclatasvir, glecaprevir, pibrentasvir, paritaprevir, simeprevir, velpatasvir, and voxilaprevir (Table 2).

Losartan is also a substrate of CYP2C9 and CYP3A4; however, these enzymes are responsible for $14 \%$ of its bioactivation into a more pharmacologically active metabolite [32]. As this is only a small amount, we do not expect a clinical relevant DDI between losartan and, for example, PrOD.

The renin inhibitor aliskiren is a CYP3A4, P-gp, and OAPT1B1 substrate. Aliskiren has not been studied with any of the DAA regimens; however, it is widely shown in the literature that aliskiren pharmacokinetics are affected by inhibitors of these enzymes and transporters [33-36]. For example, in combination with itraconazole (CYP3A4 and P-gp inhibitor) the steady-state AUC and $C_{\max }$ of aliskiren increased 6.5- and 5.8-fold [34], and with ciclosporin (cyclosporine) (CYP3A4 and P-gp inhibitor) the AUC and $C_{\max }$ increased $\sim 2.5$ - and $\sim 5$-fold, respectively [35]. Therefore, aliskiren is contraindicated with glecaprevir/pibrentasvir and $\operatorname{PrO}(\mathrm{D})$ and not recommended with daclatasvir, ledipasvir/ sofosbuvir, and simeprevir.

\subsection{Diuretics}

\subsubsection{CVDs as Victims}

The only two diuretics listed in Table 2 that might have a DDI are furosemide and eplerenone. Furosemide was studied in combination with PrOD. Furosemide is glucuronidated and the study showed that, in particular, the $C_{\max }$ increased by $50 \%$ as paritaprevir, ombitasvir, and dasabuvir all inhibit UGT1A1 [23, 37]. Thus, the label recommends monitoring of, for example, the patient's blood pressure and reduction of the dose by $50 \%$ when necessary.

Eplerenone (aldosterone antagonist) is involved in DDIs as it is metabolized by CYP3A4. As no interaction studies were found with eplerenone and many of the DAAs inhibit CYP3A4, we advise care be taken and that treatment be initiated with a lower dose (e.g., 50\% reduced) when combined with grazoprevir/elbasvir, glecaprevir/pibrentasvir, and simeprevir. The drug is contraindicated with the ritonavircontaining regimens [38].

\subsection{Calcium Channel Blockers}

\subsubsection{CVDs as Perpetrators}

The calcium antagonist verapamil is an inhibitor of P-gp, making it a perpetrator of DDIs with P-gp substrates, which are almost all DAAs (Table 2). When verapamil and DAAs are combined it is recommended that the side effects of the DAAs be monitored. It should be mentioned that most DAAs have a wide therapeutic range and have a favorable safety profile, so this interaction is probably not clinically relevant.

\subsubsection{CVDs as Victims}

In general, calcium channel blockers are CYP3A4 substrates and therefore have DDIs with the DAAs that inhibit this enzyme. So, it is advisable that the heart rate and blood pressure be monitored when patients are treated with both calcium channel blockers and DAAs.

Paritaprevir exposure was reduced $\sim 20 \%$ in combination with amlodipine, but this was not considered to be clinical relevant. The same study found that amlodipine AUC and $C_{\max }$ values increased by 157 and $26 \%$, respectively [23, 37]. Therefore, we recommend reducing the amlodipine dose by $50 \%$ when PrOD is started.

Felodipine is a CYP3A4 substrate and has been studied in combination with the weak CYP3A4 inhibitors glecaprevir/ pibrentasvir. Felodipine exposure rose by $31 \%$, which was considered not to be clinical relevant (AUC increased 31\%; $C_{\max }$ increased $31 \%$ ) and no precautions are necessary when combining these drugs $[28,29]$.

Verapamil is also a victim of DDIs with almost all DAAs as it is a substrate of CYP3A4 and P-gp. The plasma concentration of verapamil can be increased by, for example, daclatasvir, grazoprevir, elbasvir, glecaprevir, and pibrentasvir [39]. Therefore, patients using verapamil should be monitored for side effects of verapamil (blood pressure, heart rate).

\subsection{Statins and Ezetimibe}

\subsubsection{CVDs as Victims}

The statins are definitely the most frequently studied drugs in combination with DAAs. All of the DAAs (except 
sofosbuvir alone) have pharmacokinetic interactions with the different statins. For example, simvastatin was studied in combination with simeprevir, which increased the AUC and $C_{\max }$ of simvastatin by 51 and $46 \%$ [40]. This is caused by intestinal CYP3A4, OATP1B1/3, and P-gp inhibition by simeprevir, as simvastatin is a substrate of these enzymes and transporters. Therefore, when simvastatin is combined with simeprevir, the dose of simvastatin should be reduced and the patient should be monitored carefully. Even more profound increases in AUC and $C_{\max }$ were observed when atorvastatin was combined with grazoprevir (2- and $\sim 6$-fold [41], respectively) and glecaprevir/pibrentasvir ( 8- and 22-fold, respectively [28, 29, 41, 42]).

As all statins are substrates of various drug transporters and drug-metabolizing enzymes that are inhibited by DAAs, this results in a clinically relevant increase in statin plasma concentrations. These interactions must be managed at the start of HCV therapy because of the severe adverse reactions that can be expected with increased statin plasma concentrations. The risk relating to high exposure to statins has been discussed previously in different case reports [43-50], describing severe myopathy or even rhabdomyolysis, which is a potentially life-threatening condition. Therefore, for all statins we recommend that physicians take care when combining these drugs with DAAs. At the very least treatment should be initiated using the lowest dose; however, when possible in patients with a low risk of atherosclerotic cardiovascular diseases, another option is to discontinue the statin during the 8-12 weeks of HCV treatment.

Ezetimibe is not a statin, but is a substrate of OATP1B1 and could therefore have drug interactions with daclatasvir, simeprevir, glecaprevir/pibrentasvir, $\operatorname{PrO}(\mathrm{D})$, and sofosbuvir/velpatasvir/voxilaprevir. We also recommend discontinuing ezetimibe during DAA therapy.

\subsection{Fibrates}

\subsubsection{CVDs as Perpetrators}

The fibrate gemfibrozil has been studied in combination with PrOD as it strongly inhibits CYP2C8 and CYP2C9. This is one of the rare cases in which the CVD is the perpetrator of a DDI and the DAA is the victim, because dasabuvir is a CYP2C8 substrate. When combined with gemfibrozil $1200 \mathrm{mg}$ the dasabuvir AUC increased 11-fold and the $C_{\max }$ 2 -fold. As a result, gemfibrozil is contraindicated in combination with PrOD [37]. As with statins, one could consider discontinuing gemfibrozil when dasabuvir is necessary. Gemfibrozil did not influence paritaprevir and ritonavir plasma concentrations in a clinically relevant extent. Thus, as gemfibrozil solely affected dasabuvir concentrations, and ombitasvir is not a CYP2C8/9 substrate, it can be used in combination with paritraprevir/ritonavir and ombitasvir (PrO; i.e., without dasabuvir) [23].

\subsubsection{CVDs as Victims}

Gemfibrozil is also a minor CYP3A4 substrate; its plasma concentration could decrease during therapy, which is shown in combination with lopinavir/ritonavir [51]. Busse and colleagues [51] described that steady-state AUC and $C_{\max }$ values for gemfibrozil were decreased by 41 and $33 \%$ in combination with lopinavir/ritonavir. We recommend that when gemfibrozil is combined with PrO or other CYP3A4 inhibitors, the lipid profile of the patient should be monitored. But, again, it is probably best to discontinue the fibrate.

\subsection{Platelet Aggregation Inhibitors}

\subsubsection{CVDs as Victims}

No DDIs are expected with acetylsalicylic acid; however, drug interactions are definitely predicted with the other drugs from this class, but no DDI studies were identified. We expect DDIs between $\operatorname{PrO}(\mathrm{D})$ and clopidogrel, prasugrel, and ticagrelor, as CYP3A4 and CYP2C19 are involved in the bio-activation of clopidogrel and prasugrel and metabolism of ticagrelor [52-56]. As clopidogrel and prasugrel are both prodrugs with complex drug metabolism [57, 58], the pharmacokinetic relevance of these DDIs is hard to predict. When these enzymes are inhibited by ritonavir (in PrOD), it could mean that a less active metabolite is formed, causing a reduced effect on the platelet aggregation. As clopidogrel, prasugrel, and ticagrelor have not been studied with the DAAs, we now present information from other DDI studies with, amongst others, CYP3A4 inhibitors. This is done to provide more information about the influence of enzyme inhibition in combination with the complex metabolism of clopidogrel and prasugrel.

Farid and colleagues [57] studied the DDIs when clopidogrel and prasugrel were given with ketoconazole. These drugs were administered to healthy volunteers and it was shown that ketoconazole decreased the $C_{\max }$ of the active metabolite of both prasugrel and clopidogrel by 34 and $61 \%$, respectively. The AUC of the active metabolite of clopidogrel was also affected when combined with ketoconazole as it was $29 \%$ decreased. This influenced the inhibition of the platelet aggregation (pharmacodynamics). The AUC of the active metabolite of prasugrel was not affected and there was also no influence on the inhibition of the platelet aggregation [57]. These findings are strengthened by a phase I study in healthy volunteers and HIV-infected patients where the boosted protease inhibitors ritonavir and cobicistat were administered to subjects in combination with prasugrel and clopidogrel [58]. After a dose of clopidogrel $300 \mathrm{mg}$ 
and ritonavir $100 \mathrm{mg}$ or cobicistat $150 \mathrm{mg}$ the AUC from time zero to $4 \mathrm{~h}\left(\mathrm{AUC}_{4}\right)$ and $C_{\max }$ of the clopidogrel active metabolite decreased from 80.5 to $25.1 \mathrm{ng} \bullet \mathrm{mL} / \mathrm{h}$ and 55.9 to $17.3 \mathrm{ng} / \mathrm{mL}$, respectively. This decrease in AUC and $C_{\max }$ influences the pharmacodynamics as platelet inhibition was insufficient in $44 \%$ of the HIV-infected patients. Almost all healthy volunteers had sufficient platelet inhibition as they were not using a CYP3A4 inhibitor. Comparably, the $\mathrm{AUC}_{4}$ and $C_{\max }$ of the active metabolite of prasugrel were decreased from 414 to $200 \mathrm{ng} \mathrm{mL} / \mathrm{h}$ and 362 to $207 \mathrm{ng} / \mathrm{mL}$, respectively. Similar to the study of Farid et al. [57], this did not influence the pharmacodynamics of prasugrel as both healthy volunteers and HIV-infected patients had sufficient platelet inhibition. The authors argue that this is caused by the fact that prasugrel is a more potent platelet inhibitor then clopidogrel [58]. When we extrapolate the results of these two studies to the HCV-infected population, we believe prasugrel is the best choice in combination with ritonavir, and thus combination of prasugrel is also possible with the DAA-inhibiting CYP3A4 (e.g., PrO(D), simeprevir).

The pharmacokinetics of ticagrelor have also been studied in combination with CYP3A4 inhibitors (diltiazem and ketoconazole) [59]. Diltiazem and ketoconazole both inhibit CYP3A4 and P-gp and could therefore possibly affect ticagrelor exposure and thus also the pharmacodynamics. Ticagrelor itself is a direct-acting antiplatelet agent; however, it has also active metabolites. The moderate CYP3A4 and P-gp inhibitor diltiazem increased the ticagrelor $C_{\max }$ and AUC by 69 and $174 \%$, respectively. Understandably, the $C_{\max }$ and AUC of the active metabolite were decreased (38 and 13\%, respectively). Comparable but more extreme results were found with the strong CYP3A4 inhibitor ketoconazole: $C_{\max }$ and AUC were increased by 135 and 532\% and these values for the active metabolite was decreased by $89 \%$ and $56 \%$, respectively. The influence on the pharmacodynamics was not part of the study in healthy volunteers [59]. This study showed that CYP3A4 inhibitors, both moderate and strong, are not recommended in combination with ticagrelor. This same effect was studied in a physiologically based pharmacokinetic (PBPK) model showing that a reduced dose of ticagrelor $45 \mathrm{mg}$ (instead of $90 \mathrm{mg}$ ) could be adequate in combination with ritonavir. However, this has not yet been studied in vivo [60].

Based on these published drug interaction studies between clopidogrel, prasugrel, and ticagrelor and CYP3A4 inhibitors, we advise that these drugs not be used in combination with, for example, PrOD and simeprevir (also CYP3A4 inhibitors), but instead that another DAA combination be used or to switch to, for example, acetylsalicylic acid. However, in the exceptional situation in which both a platelet inhibitor other than acetylsalicylic acid is needed and $\mathrm{PrOD}$ or simeprevir is indicated, the preferred platelet aggregation inhibitor would be prasugrel.

\subsection{Vitamin K Antagonists}

\subsubsection{CVDs as Victims}

Acenocoumarol, phenprocoumon, and warfarin are all metabolized by CYP enzymes such as CYP2C9, CYP1A2, and CYP3A4 (Table 1). Phenprocoumon is also glucuronidated. These enzymes can be influenced by different DAAs, causing DDIs as presented in Table 2. Acenocoumarol and phenprocoumon have not been studied in vivo with DAAs, but warfarin has been studied in combination with PrOD and simeprevir. The GMR and $C_{\max }$ of S-warfarin was not influenced by simeprevir [40]. Comparable results are found for both R- and S-Warfarin, after a dose of warfarin $5 \mathrm{mg}$, when combined with PrOD. For this combination, the label advises that the dose of warfarin should not be altered, but that the INR should be monitored during DAA treatment [37]. DDIs with vitamin $K$ antagonists can be managed easily, as the INR can be easily and frequently monitored.

\subsection{Heparin Group and Fondaparinux}

No DDI studies were found and no CYPs are involved in the metabolism of heparin, nadroparin, dalteparin, and enoxaparin, and therefore no DDIs are expected.

\subsection{Direct Factor Xa Inhibitors}

\subsubsection{CVDs as Victims}

The direct factor Xa inhibitors have all been marketed recently and therefore adequate information is available regarding drug metabolism and drug interactions. All direct factor $\mathrm{Xa}$ inhibitors are $\mathrm{P}$-gp substrates, making them victims of DDIs. This resulted in an increased dabigatran AUC and $C_{\max }$ when combined with glecaprevir/pibrentasvir of 138 and 105\%, respectively [28, 29]. Comparable numbers were also found when dabigatran was combined with sofosbuvir/velpatasvir/voxilaprevir as AUC and $C_{\max }$ values were elevated by 161 and $187 \%$, respectively [61, 62]. These increased plasma concentrations, which could potentially cause extreme bleeding, are the reason why dabigatran is contraindicated with both glecaprevir/pibrentasvir and sofosbuvir/velpatasvir/voxilaprevir. As all other available DAA regimens also inhibit P-gp, dabigatran should be used with caution in combination with all DAAs. Switching to other anticoagulation therapy would possibly be best in these cases.

No DDI studies were found involving DAAs and the other direct factor Xa inhibitors, but based on metabolism and studies with other P-gp inhibitors the recommendations are the same as for dabigatran regarding P-gp inhibition. The exception is edoxaban, which, according to its label, 
is contraindicated with sofosbuvir/velpatasvir/voxilaprevir; one of the active metabolites of edoxaban is a substrate of OATP1B1, which is inhibited by both velpatasvir as voxilaprevir. Also, some other DAAs inhibit both P-gp and OATP1B1, and precribers should be careful when using DAAs together with edoxaban. When combining edoxaban with $\operatorname{PrO}(\mathrm{D})$ and glecaprevir/pibrentasvir, a reduced dose of $30 \mathrm{mg}$ can also be considered; however, this has not been studied and is not recommended by the edoxaban label. Body weight $(<60 \mathrm{~kg})$ and renal function should be considered when reducing the dose [63].

As well as being a P-gp substrate, both apixaban and rivaroxaban are also CYP3A4 substrates. Thus, these drugs are contraindicated with $\operatorname{PrO}(\mathrm{D})$ as their labels contraindicate strong CYP3A4 substrates and P-gp inhibitors, such as ritonavir. For example, the steady-state exposure of apixaban and its $C_{\max }$ were elevated by 2 - and 1.6-fold, respectively, when combined with ketoconazole $[64,65]$.

\subsection{Nitrates}

The nitrates are hepatically metabolized (Table 1), but no CYPs are involved (as far as we know). Therefore, it is not expected that there will be any drug interactions between the nitrates and DAA regimens.

\subsection{Amiodarone and Digoxin}

\subsubsection{CVDs as Victims}

We found no studies of DDIs between the DAAs and amiodarone. However, amiodarone is contraindicated with all sofosbuvir-based regimens. This is based on an FDA warning and case reports describing extreme bradycardia and even death in patients treated with sofosbuvir-based regimens together with amiodarone [12,66-68]. The exact mechanism of the DDI is still unknown [69-74], but several in vitro and in vivo studies have been performed with the aim of understanding this severe, and widely discussed, drug interaction. For example, Lagrutta et al. [70] recently published data showing a pharmacodynamic interaction between sofosbuvir (L-Ala diastereoisomer) and amiodarone. When sofosbuvir was coadministered with amiodarone an increased beating rate and decreased beat amplitude in pluripotent stem cell-derived cardiomyocytes was observed. This finding was confirmed in Dunkin-Hartley guinea pigs. The authors show that the interaction between NS5B polymerase inhibitors is dependent of the diastereochemistry of the specific drugs, which showed no alterations in rate and amplitude when they studied MK-3682 (D-Ala diastereoisomer) [70].
As the precise mechanism and the DAA that caused the drug interaction is not totally clear, all sofosbuvir-containing regimens are contraindicated with amiodarone. No DDIs or assumed mechanisms are known for elbasvir/grazoprevir and glecaprevir/pibrentasvir, so these DAA regimens may be combined with amiodarone. We do, however, recommend being careful as little is known about the amiodarone interaction with the sofosbuvir-based regimens and this severe drug interaction was also not predicted by drug metabolism or drug transport.

Digoxin is probably the best studied drug in combination with DAAs, as shown in Table 3. Digoxin is a P-gp substrate and often used in DDI studies as a 'P-gp probe'. Digoxin has been studied in combination with daclatasvir, simeprevir, elbasvir/grazoprevir, glecaprevir/pibrentasvir, $\operatorname{PrO}(\mathrm{D})$, and velpatasvir. When P-gp is inhibited, absorption is increased, resulting in higher $C_{\max }$ values. This is also shown in the different DDI studies with the DAAs (Table 3). For example, in combination with elbasvir/grazoprevir the AUC and $C_{\max }$ of digoxin increased by 11 and $47 \%$, respectively [41]. In comparison, when combined with velpatasvir the AUC and $C_{\max }$ increased by 34 and $88 \%$, respectively [75]. For this reason, digoxin can be coadministered with DAAs with frequent monitoring of digoxin plasma concentrations, especially when digoxin is started during DAA therapy. It is advised to start with the lowest possible digoxin dose. When starting DAA therapy while on digoxin, an increase in the digoxin $C_{\max }$ is expected, as the DAAs have the biggest influence on the $C_{\max }$ (absorption phase). Therefore, we recommend that the intake of the DAAs and digoxin be separated as the data show a limited influence on the AUC, therefore suggesting that when the intake of the drug is separated the magnitude of the interaction might be reduced. This concept has not yet been studied, but we recommend this to our patients who are in need of both digoxin and DAA therapy. Of course, consulting a cardiologist for a baseline ECG is a must in these cases in combination with measuring the digoxin toxicity and plasma concentrations.

\section{Concluding Remarks}

In this descriptive review we aimed to provide an overview of all known DDIs between selected CVDs and the DAAs licensed in Europe and the USA and to give recommendations to aid clinical decision-making for clinical pharmacologists managing the DDIs together with prescribers. Our most significant finding was that there are few in vivo drug interactions studies between the two drug classes. Most DDI studies used for this review were found in the drug labels and not in other publications or posters in the public domain. Thus, few DDI studies have been performed after licensing. One could argue that for the frequently prescribed drugs 
such as clopidogrel, prasugrel, and ticagrelor there is a need for DDI studies with the DAAs. This could be in the form of clinical studies, but more and more frequently modeling and simulation (in silico) studies are undertaken to evaluate drug interactions. For example, PBPK modeling is a frequently used approach for studying DDIs in silico [72, 76], reducing the number of in vivo drug interaction studies needed.

Throughout this review, many drug interactions are described that are the result of the ritonavir in the $\operatorname{PrO}(\mathrm{D})$ combination. It should be noted that with the introduction of newer DAA regimens such as sofosbuvir/velpatasvir with or without voxilaprevir and glecaprevir/pibrentasvir the number of clinically relevant drug interactions will reduce significantly because these regimens have more favorable drug interaction profiles. Still, these newer DAAs are also involved in drug interactions (Tables 3 and 4) and do not obviate the risk of DDIs with CVDs.

Most DDIs can be managed easily in daily practice by monitoring the efficacy and toxicity of the victim drug, switching to another CVD in the same class, or switching to another DAA.

Another interesting finding is that, in general, the CVDs are the victims of the DDIs. Thus, monitoring of blood pressure, low-density lipoprotein, and the INR is recommended when coadministering these drugs with DAAs. Nevertheless, it is sometimes probably just better to discontinue a drug on a temporary basis (i.e., statins). The DAAs are victims of the DDIs in combination with, for example, verapamil and gemfibrozil, for which alternative options are given. In addition, the DAAs in general have a wide therapeutic range, so when the plasma concentration is decreased or increased we do not expect severe loss of efficacy or toxicity.

In conclusion, this review provides an overview of the mechanisms of drug interactions between CVDs and DAAs. We used interaction studies to make predictions regarding possible DDIs and provide advice on how to handle these predicted drug interactions. It would be best if, in the future, these predictions are strengthened with data from in vivo drug interaction studies in order to safely optimize treatment of $\mathrm{HCV}$ patients with DAAs.

\section{Compliance with Ethical Standards}

Conflict of interest EJS declares having received travels grants from Abbvie and Gilead. SW and PJGTH declare that they have no conflicts of interest that are directly relevant to the content of this review. DMB is on the advisory boards for AbbVie, BMS, Gilead, Janssen, and Merck and received sponsorship/research grants from BMS, Gilead, Janssen, Merck, and Viiv. However, these conflicts of interest did not influence the preparation of this review.

Funding No funding was used in the preparation of this review.
Open Access This article is distributed under the terms of the Creative Commons Attribution-NonCommercial 4.0 International License (http://creativecommons.org/licenses/by-nc/4.0/), which permits any noncommercial use, distribution, and reproduction in any medium, provided you give appropriate credit to the original author(s) and the source, provide a link to the Creative Commons license, and indicate if changes were made.

\section{References}

1. Burger D, Back D, Buggisch P, Buti M, Craxi A, Foster G, et al. Clinical management of drug-drug interactions in $\mathrm{HCV}$ therapy: challenges and solutions. J Hepatol. 2013;58(4):792-800.

2. El-Sherif O, Khoo S, Solas C. Key drug-drug interactions with direct-acting antiviral in HIV-HCV coinfection. Curr Opin HIV AIDS. 2015;10(5):348-54.

3. Kiser JJ, Burton JR Jr, Everson GT. Drug-drug interactions during antiviral therapy for chronic hepatitis C. Nat Rev Gastroenterol Hepatol. 2013;10(10):596-606.

4. Lauffenburger JC, Mayer CL, Hawke RL, Brouwer KLR, Fried MW, Farley JF. Medication use and medical comorbidity in patients with chronic hepatitis $\mathrm{C}$ from a US commercial claims database: high utilization of drugs with interaction potential. Eur J Gastroenterol Hepatol. 2014;2014(26):1073-82.

5. Vermehren J, Peiffer KH, Welsch C, Grammatikos G, Welker MW, Weiler N, et al. The efficacy and safety of direct acting antiviral treatment and clinical significance of drug-drug interactions in elderly patients with chronic hepatitis $\mathrm{C}$ virus infection. Aliment Pharmacol Ther. 2016;44(8):856-65.

6. Smolders EJ, Smit C, De Kanter CT, Dofferiiof ASM, Arends JE, Brinkman K, et al. Brief report: high need to switch cART or comedication with the initiation of DAAs in elderly HIV/ HCV-coinfected patients. J Acquir Immune Defic Syndr. 2017;76(2):193-9.

7. Smolders EJ, Smit C, de Kanter C, Dofferhoff A, Arends JE, Brinkman K, et al. Management of drug interactions with directacting antivirals in Dutch HIV/hepatitis C virus-coinfected patients: adequate but not perfect. HIV Med. 2018;19(3):216-26.

8. Smolders EJ, Berden FA, de Kanter CT, Kievit W, Drenth JP, Burger DM. The majority of hepatitis $C$ patients treated with direct acting antivirals are at risk for relevant drug-drug interactions. United Eur Gastroenterol J. 2017;5(5):648-57.

9. Negro F. Facts and fictions of HCV and comorbidities: steatosis, diabetes mellitus, and cardiovascular diseases. J Hepatol. 2014;61(1 Suppl):S69-78.

10. Møller S, Bendtsen F. Complications of cirrhosis. A 50 years flashback. Scand J Gastroenterol. 2015;50(6):763-80.

11. de Lorenzo-Pinto A, Gimenez-Manzorro A, Rodriguez-Gonzalez CG, Ahumada-Jimenez A, Herranz-Alonso A, MarzalAlfaro MB, et al. Decreased INR after acenocoumarol, ombitasvir/paritaprevir/ritonavir and dasabuvir co-administration. J Clin Pharm Ther. 2016;41(4):444-6.

12. Renet S, Chaumais MC, Antonini T, Zhao A, Thomas L, Savoure A, et al. Extreme bradycardia after first doses of sofosbuvir and daclatasvir in patients receiving amiodarone: 2 cases including a rechallenge. Gastroenterology. 2015;149(6):1378. e1-1380.e1.

13. Fontaine H, Lazarus A, Pol S, Pecriaux C, Bagate F, Sultanik P, et al. Bradyarrhythmias associated with sofosbuvir treatment. N Engl J Med. 2015;373(19):1886-8.

14. Giacomini KM, Huang SM. Transporters in drug development and clinical pharmacology. Clin Pharmacol Ther. 2013;94(1):3-9. 
15. Bahar MA, Setiawan D, Hak E, Wilffert B. Pharmacogenetics of drug-drug interaction and drug-drug-gene interaction: a systematic review on CYP2C9, CYP2C19 and CYP2D6. Pharmacogenomics. 2017;18(7):701-39.

16. FDA. Coreg: prescribing information. https://s3-us-west-2.amazo naws.com/drugbank/fda_labels/DB01136.pdf?1265922801. Accessed 6 Mar 2018.

17. Boglione L, De Nicolo A, Mornese Pinna S, Cusato J, Favata F, Ariaudo A, et al. Role of simeprevir plasma concentrations in HCV treated patients with dermatological manifestations. Dig Liver Dis. 2017;49(6):705-8.

18. EMA. Sovaldi: summary of product characteristics. 2014. http://www.ema.europa.eu/docs/en_GB/document_library/ EPAR_-_Product_Information/human/002798/WC50016059 7.pdf. Accessed 7 Mar 2018.

19. FDA. Sovaldi: prescribing information. 2014. http://www.acces sdata.fda.gov/drugsatfda_docs/label/2014/204671s001lbl.pdf. Accessed 7 Mar 2018.

20. Garimella T, Tao X, Sims K, Chang Y-T, Rana J, Myers E, et al. Effects of a fixed-dose co-formulation of daclatasvir, asunaprevir, and beclabuvir on the pharmacokinetics of a cocktail of cytochrome P450 and drug transporter substrates in healthy subjects. Drugs R\&D. 2018;18(1):55-65.

21. EMA. Daklinza: summary of product characteristics. 2015. http://www.ema.europa.eu/docs/en_GB/document_library/ EPAR_-_Product_Information/human/003768/WC50017284 8.pdf. Accessed 7 Mar 2018.

22. FDA. Daklinza: prescribing information. 2015. http://www.acces sdata.fda.gov/drugsatfda_docs/label/2015/206843Orig1s000lbl. pdf. Accessed 7 Mar 2018.

23. EMA. Viekirax: summary of product characteristics. 2015. http://www.ema.europa.eu/docs/en_GB/document_library/ EPAR___Product_Information/human/003839/WC50018399 7.pdf. Accessed 7 Mar 2018.

24. FDA. Viekira Pak: prescribing information. 2014. https://www. accessdata.fda.gov/drugsatfda_docs/label/2014/206619lbl.pdf. Accessed 7 Mar 2018.

25. Skinner MH, Kuan HY, Pan A, Sathirakul K, Knadler MP, Gonzales CR, et al. Duloxetine is both an inhibitor and a substrate of cytochrome P4502D6 in healthy volunteers. Clin Pharmacol Ther. 2003;73(3):170-7.

26. EMA. Norvir: summary of product characteristics. 2014. http:// www.ema.europa.eu/docs/en_GB/document_library/EPAR_-Product_Information/human/000127/WC500028728.pdf. Accessed 30 Jun 2016.

27. Liu L, Cui Y, Chung AY, Shitara Y, Sugiyama Y, Keppler D, et al. Vectorial transport of enalapril by Oatp1a1/Mrp2 and OATP1B1 and OATP1B3/MRP2 in rat and human livers. J Pharmacol Exp Ther. 2006;318(1):395-402.

28. EMA. Maviret: summary of product characteristics. 2017. http://www.ema.europa.eu/docs/en_GB/document_library/ EPAR_-_Product_Information/human/004430/WC50023367 7.pdf. Accessed 7 Mar 2018.

29. FDA. Mavyret: prescribing information. 2017. https://www. accessdata.fda.gov/drugsatfda_docs/label/2017/209394s000 1bl.pdf. Accessed 7 Mar 2018.

30. Chapy H, Klieber S, Brun P, Gerbal-Chaloin S, Boulenc X, Nicolas O. PBPK modeling of irbesartan: incorporation of hepatic uptake. Biopharm Drug Dispos. 2015;36(8):491-506.

31. Ishiguro N, Maeda K, Kishimoto W, Saito A, Harada A, Ebner T, et al. Predominant contribution of OATP1B3 to the hepatic uptake of telmisartan, an angiotensin II receptor antagonist, in humans. Drug Metab Dispos. 2006;34(7):1109-15.

32. FDA. Hyzaar: prescribing information. 2011. https://www. accessdata.fda.gov/drugsatfda_docs/label/2011/020387s052 lbl.pdf. Accessed 6 Mar 2018.
33. Rebello S, Leon S, Hariry S, Dahlke M, Jarugula V. Effect of verapamil on the pharmacokinetics of aliskiren in healthy participants. J Clin Pharmacol. 2011;51(2):218-28.

34. Tapaninen T, Backman JT, Kurkinen KJ, Neuvonen PJ, Niemi M. Itraconazole, a P-glycoprotein and CYP3A4 inhibitor, markedly raises the plasma concentrations and enhances the renin-inhibiting effect of aliskiren. J Clin Pharmacol. 2011;51(3):359-67.

35. Rebello S, Compain S, Feng A, Hariry S, Dieterich HA, Jarugula V. Effect of cyclosporine on the pharmacokinetics of aliskiren in healthy subjects. J Clin Pharmacol. 2011;51(11):1549-60.

36. Vaidyanathan S, Camenisch G, Schuetz H, Reynolds C, Yeh $\mathrm{CM}$, Bizot MN, et al. Pharmacokinetics of the oral direct renin inhibitor aliskiren in combination with digoxin, atorvastatin, and ketoconazole in healthy subjects: the role of P-glycoprotein in the disposition of aliskiren. J Clin Pharmacol. 2008;48(11):1323-38.

37. EMA. Exviera: summary of product characteristics. 2015. http://www.ema.europa.eu/docs/en_GB/document_library/ EPAR_-_Product_Information/human/003837/WC50018223 3.pdf. Accessed 7 Mar 2018.

38. FDA. Inspra: prescribing information. 2002. https://www.acces sdata.fda.gov/drugsatfda_docs/label/2016/021437s013lbl.pdf. Accessed 6 Mar 2018

39. FDA. Verelan: prescribing information. 2014. https://www.acces sdata.fda.gov/drugsatfda_docs/label/2014/019614s050lbl.pdf. Accessed 6 Mar 2018.

40. EMA. Olysio: summary of product characteristics. 2014. http:// ec.europa.eu/health/documents/community-register/2014/20140 514128513/anx_128513_en.pdf. Accessed 7 Mar 2018.

41. EMA. Zepatier: summary of product characteristics. 2016. http://www.ema.europa.eu/docs/en_GB/document_library/ EPAR_-_Product_Information/human/004126/WC50021123 5.pdf. Accessed 7 Mar 2018.

42. FDA. Zepatier: prescribing information. 2016. http://www.acces sdata.fda.gov/drugsatfda_docs/label/2016/208261Orig 1s000lbl. pdf. Accessed 7 Mar 2018.

43. Kanter CT, Luin M, Solas C, Burger DM, Vrolijk JM. Rhabdomyolysis in a hepatitis $\mathrm{C}$ virus infected patient treated with telaprevir and simvastatin. Ann Hepatol. 2014;13(4):452-5.

44. Cheng CH, Miller C, Lowe C, Pearson VE. Rhabdomyolysis due to probable interaction between simvastatin and ritonavir. Am $\mathrm{J}$ Health Syst Pharm. 2002;59(8):728-30.

45. Aboulafia DM, Johnston R. Simvastatin-induced rhabdomyolysis in an HIV-infected patient with coronary artery disease. AIDS Patient Care STDS. 2000;14(1):13-8.

46. Schmidt GA, Hoehns JD, Purcell JL, Friedman RL, Elhawi Y. Severe rhabdomyolysis and acute renal failure secondary to concomitant use of simvastatin, amiodarone, and atazanavir. J Am Board Fam Med. 2007;20(4):411-6.

47. Martin CM, Hoffman V, Berggren RE. Rhabdomyolysis in a patient receiving simvastatin concurrently with highly active antriretroviral therapy [abstract no. 1297]. 40th ICAAC; 17-20 2000; Toronto.

48. Mah Ming JB, Gill MJ. Drug-induced rhabdomyolysis after concomitant use of clarithromycin, atorvastatin, and lopinavir/ritonavir in a patient with HIV. AIDS Patient Care STDS. 2003;17(5):207-10.

49. Hare CB, Vu MP, Grunfeld C, Lampiris HW. Simvastatin-nelfinavir interaction implicated in rhabdomyolysis and death. Clin Infect Dis. 2002;35(10):e111-2.

50. Castro JG, Gutierrez L. Rhabdomyolysis with acute renal failure probably related to the interaction of atorvastatin and delavirdine. Am J Med. 2002;112(6):505.

51. Busse KH, Hadigan C, Chairez C, Alfaro RM, Formentini E, Kovacs JA, et al. Gemfibrozil concentrations are significantly 
decreased in the presence of lopinavir-ritonavir. J Acquir Immune Defic Syndr. 2009;52(2):235-9.

52. EMA. Plavix: summary of product characteristics. 2008. http:// www.ema.europa.eu/docs/en_GB/document_library/EPAR_-Product_Information/human/000174/WC500042189.pdf. Accessed 6 Mar 2018.

53. FDA. Plavix: prescribing information. 2009. https://www.acces sdata.fda.gov/drugsatfda_docs/label/2009/020839s044lbl.pdf. Accessed 6 Mar 2018.

54. FDA. Effient: prescribing information. 2009. https://www.acces sdata.fda.gov/drugsatfda_docs/label/2010/022307s002lbl.pdf. Accessed 6 Mar 2018.

55. EMA. Efient: summary of product characteristics. 2009. http:// www.ema.europa.eu/docs/en_GB/document_library/EPAR_-Product_Information/human/000984/WC500021971.pdf. Accessed 6 Mar 2018.

56. EMA. Brilique: summary of product characteristics. 2010. http://www.ema.europa.eu/docs/en_GB/document_library/ EPAR_-_Product_Information/human/001241/WC50010049 4.pdf. Accessed 6 Mar 2018.

57. Farid NA, Payne CD, Small DS, Winters KJ, Ernest CS 2nd, Brandt JT, et al. Cytochrome P450 3A inhibition by ketoconazole affects prasugrel and clopidogrel pharmacokinetics and pharmacodynamics differently. Clin Pharmacol Ther. 2007;81(5):735-41.

58. Marsousi N, Daali Y, Fontana P, Reny JL, Ancrenaz-Sirot V, Calmy A, et al. Impact of boosted antiretroviral therapy on the pharmacokinetics and efficacy of clopidogrel and prasugrel active metabolites. Clin Pharmacokinet. 2018. https://doi. org/10.1007/s40262-018-0637-6.

59. Teng R, Butler K. Effect of the CYP3A inhibitors, diltiazem and ketoconazole, on ticagrelor pharmacokinetics in healthy volunteers. J Drug Assess. 2013;2(1):30-9.

60. Marsousi N, Samer CF, Fontana P, Reny JL, Rudaz S, Desmeules JA, et al. Coadministration of ticagrelor and ritonavir: toward prospective dose adjustment to maintain an optimal platelet inhibition using the PBPK approach. Clin Pharmacol Ther. 2016;100(3):295-304.

61. EMA. Vosevi: summary of product characteristics. 2017. http:// www.ema.europa.eu/docs/en_GB/document_library/EPAR_Product_Information/human/004350/WC500235373.pdf. Accessed 7 Mar 2018.

62. FDA. Vosevi: prescribing information. 2017. https://www.acces sdata.fda.gov/drugsatfda_docs/label/2017/209195s0001bl.pdf. Accessed 7 Mar 2018

63. EMA. Lixiana: summary of product characteristics. 2015. http://www.ema.europa.eu/docs/en_GB/document_library/ EPAR_-_Product_Information/human/002629/WC50018904 5.pdf. Accessed 6 Mar 2018.

64. EMA. Eliquis: summary of product characteristics. 2011. http:// www.ema.europa.eu/docs/en_GB/document_library/EPAR_-Product_Information/human/002148/WC500107728.pdf. Accessed 6 Mar 2018.

65. FDA. Eliquis: prescribing information. 2012. https://www.acces sdata.fda.gov/drugsatfda_docs/label/2016/202155s012lbl.pdf. Accessed 6 Mar 2018

66. Regan CP, Morissette P, Regan HK, Travis JJ, Gerenser P, Wen $\mathrm{J}$, et al. Assessment of the clinical cardiac drug-drug interaction associated with the combination of hepatitis $\mathrm{C}$ virus nucleotide inhibitors and amiodarone in guinea pigs and rhesus monkeys. Hepatology. 2016;64(5):1430-41.

67. Important drug warning. Serious and life-threatening cases of symptomatic bradycardia as well as one case of fatal cardiac arrest reported with coadministration of amiodarone with either Harvoni ${ }^{\circledR}$ (ledipasvir and sofosbuvir fixed-dose combination) or with Sovaldi ${ }^{\circledR}$ (sofosbuvir) in combination with another direct acting antiviral. Dear Healthcare Provider letter: Gilead Sciences, 20 March 2015. 2015. http://www.natap.org/2015/HCV/SVD20 March15FINAL-1.pdf

68. FDA. FDA warns of serious slowing of the heart rate when the antiarrhythmic drug amiodarone us used with hepatitis $\mathrm{C}$ treatments containing sofosbuvir (Harvoni) or Sovaldi in combination with another direct acting antiviral drug. https://www.fda.gov/ Drugs/DrugSafety/ucm439484.htm. Accessed 17 May 2015.

69. Back DJ, Burger DM. Interaction between amiodarone and sofosbuvir-based treatment for hepatitis $\mathrm{C}$ virus infection: potential mechanisms and lessons to be learned. Gastroenterology. 2015;149(6):1315-7.

70. Lagrutta A, Zeng H, Imredy J, Balasubramanian B, Dech S, Lis $\mathrm{E}$, et al. Interaction between amiodarone and hepatitis- $\mathrm{C}$ virus nucleotide inhibitors in human induced pluripotent stem cellderived cardiomyocytes and HEK-293 Cav1.2 over-expressing cells. Toxicol Appl Pharmacol. 2016;1(308):66-76.

71. Caldeira D, Rodrigues FB, Duarte MM, Sterrantino C, Barra M, Goncalves N, et al. Cardiac harms of sofosbuvir: systematic review and meta-analysis. Drug Saf. 2018;41(1):77-86.

72. Chen Y, Mao J, Hop CE. Physiologically based pharmacokinetic modeling to predict drug-drug interactions involving inhibitory metabolite: a case study of amiodarone. Drug Metab Dispos. 2015;43(2):182-9.

73. Millard DC, Strock CJ, Carlson CB, Aoyama N, Juhasz K, Goetze TA, et al. Identification of drug-drug interactions in vitro: a case study evaluating the effects of sofosbuvir and amiodarone on hiPSC-derived cardiomyocytes. Toxicol Sci. 2016;154(1):174-82.

74. Regan CP, Morissette P, Regan HK, Travis JJ, Gerenser P, Wen $\mathrm{J}$, et al. Assessment of the clinical cardiac drug-drug interaction associated with the combination of hepatitis $\mathrm{C}$ virus nucleotide inhibitors and amiodarone in guinea pigs and rhesus monkeys. Hepatology. 2016;64(5):1430-41.

75. EMA. Epclusa: summary of product characteristics. 2016 http://www.ema.europa.eu/docs/en_GB/document_library/ EPAR_-_Product_Information/human/004210/WC50021115 1.pdf. Accessed 7 Mar 2018.

76. Almond LM, Mukadam S, Gardner I, Okialda K, Wong S, Hatley $\mathrm{O}$, et al. Prediction of drug-drug interactions arising from CYP3A induction using a physiologically based dynamic model. Drug Metab Dispos. 2016;44(6):821-32.

77. FDA. Atenolol: prescribing information. 2007. https:// s3-us-west-2.amazonaws.com/drugbank/fda_labels/DB003 35.pdf?1461363666. Accessed 6 Mar 2018.

78. FDA. Ziac: prescribing information. 2007. https://www.acces sdata.fda.gov/drugsatfda_docs/label/2007/020186s023lbl.pdf. Accessed 6 Mar 2018.

79. Dutch Medicines Evaluation Board (CBG). Labetalol ratiopharm: productinformatie. 2017. https://db.cbg-meb.nl/IB-teksten/h1110 6.pdf. Accessed 6 Mar 2018.

80. FDA. Metoprolol extended-release tablets: prescribing information. 2007. https://www.accessdata.fda.gov/drugsatfda_docs/ label/2008/019962s036lbl.pdf. Accessed 6 Mar 2018.

81. FDA. Byvalson: prescribing information. 2016. https://www. accessdata.fda.gov/drugsatfda_docs/label/2016/206302s000lbl. pdf. Accessed 6 Mar 2018.

82. FDA. Propranolol hydrochloride extended-release capsules: prescribing information. https://www.accessdata.fda.gov/drugsatfda _docs/label/2011/018553s037lbl.pdf. Accessed 6 Mar 2018.

83. FDA. Sotalol hydrochloride injection: prescribing information. 1992. https://www.accessdata.fda.gov/drugsatfda_docs/label /2009/022306s000lbl.pdf. Accessed 6 Mar 2018. 
84. FDA. Capoten: prescribing information. 2015. https://www.acces sdata.fda.gov/drugsatfda_docs/label/2015/018343s086lbl.pdf. Accessed 6 Mar 2018.

85. FDA. Vaseretic: prescribing information. 2011. https://www. accessdata.fda.gov/drugsatfda_docs/label/2011/019221s0411bl. pdf. Accessed 6 Mar 2018.

86. FDA. Monopril: prescribing information. 2002. https://www. accessdata.fda.gov/drugsatfda_docs/label/2003/19915se5-037_ monopril_lbl.pdf. Accessed 6 Mar 2018.

87. FDA. Zestorectic: prescribing information. 2012. https://www. accessdata.fda.gov/drugsatfda_docs/label/2012/019888s052lbl. pdf. Accessed 6 Mar 2018.

88. FDA. Aceon: prescribing information. 2012. https://www.acces sdata.fda.gov/drugsatfda_docs/label/2012/020184s019lbl.pdf. Accessed 6 Mar 2018

89. FDA. Accuretic: prescribing information. 2013. https://www. accessdata.fda.gov/drugsatfda_docs/label/2013/020125s015lbl. pdf. Accessed 6 Mar 2018.

90. FDA. Altace: prescribing information. 2013. https://www.acces sdata.fda.gov/drugsatfda_docs/label/2013/019901s060lbl.pdf. Accessed 6 Mar 2018.

91. FDA. Atacand: prescribing information. 2015. https://www.acces sdata.fda.gov/drugsatfda_docs/label/2016/021093s019lbl.pdf. Accessed 6 Mar 2018.

92. FDA. Avalide: prescribing information. 1997. https://www.acces sdata.fda.gov/drugsatfda_docs/label/2016/020758s070lbl.pdf. Accessed 6 Mar 2018.

93. EMA. Irbesartan teva: summary of producht characteristics. 2009. http://www.ema.europa.eu/docs/en_GB/document_libra ry/EPAR_-_Product_Information/human/001093/WC50003610 5.pdf. Accessed 6 Mar 2018.

94. FDA. Benicar HCT: prescribing information. 2006. https://www. uptodate.com/contents/olmesartan-drug-information?sourc $\mathrm{e}=$ preview\&search=olmesartan\&anchor $=$ F9837691\#F9837691. Accessed 6 Mar 2018

95. FDA. Micardis HCT: prescribing information. 2014. https:// www.accessdata.fda.gov/drugsatfda_docs/label/2014/02116 2s037lbl.pdf. Accessed 6 Mar 2018.

96. FDA. Exforge: prescribing information. 2007. https://www.acces sdata.fda.gov/drugsatfda_docs/label/2012/021990s017lbl.pdf. Accessed 6 Mar 2018.

97. FDA. Tekamlo: prescribing information. 2010. https://www.acces sdata.fda.gov/drugsatfda_docs/label/2015/022545s017lbl.pdf. Accessed 6 Mar 2018.

98. Dutch Medicines Evaluation Board (CBG). Amiloride: summary of product characteristics. 2013. https://db.cbg-meb.nl/IB-tekst en/h11128.pdf. Accessed 6 Mar 2018.

99. FDA. Bumex: prescribing information. 2017. https://www.acces sdata.fda.gov/drugsatfda_docs/label/2017/018225s026lbl.pdf. Accessed 6 Mar 2018.

100. FDA. Diuril: prescribing information. 2008. https://www.acces sdata.fda.gov/drugsatfda_docs/label/2009/011870s0401bl.pdf. Accessed 6 Mar 2018.

101. FDA. Furosemide tablets USP: prescribing information. 2017. https://www.accessdata.fda.gov/drugsatfda_docs/label /2017/018823s044lbl.pdf. Accessed 6 Mar 2018.

102. FDA. Lozol: prescribing information. 2005. https://www.acces sdata.fda.gov/drugsatfda_docs/label/2009/018538s0281bl.pdf. Accessed 6 Mar 2018

103. FDA. Carospir: prescribing information. 1960. https://www.acces sdata.fda.gov/drugsatfda_docs/label/2017/209478s000lbl.pdf. Accessed 6 Mar 2018.

104. FDA. Maxzide: prescribing information. 2011. https://www.acces sdata.fda.gov/drugsatfda_docs/label/2011/019129s0431bl.pdf. Accessed 6 Mar 2018.
105. FDA. Lotrel: prescribing information. 1995. https://www.acces sdata.fda.gov/drugsatfda_docs/label/2017/020364s065lbl.pdf. Accessed 6 Mar 2018.

106. Dutch Medicines Evaluation Board (CBG). Cyress: summary of product characteristics. 2013. https://db.cbg-meb.nl/IB-teksten/ h20554.pdf. Accessed 6 Mar 2018.

107. FDA. Cardizem LA: prescribing information. 1982. https://www. accessdata.fda.gov/drugsatfda_docs/label/2015/021392s0191bl. pdf. Accessed 6 Mar 2018.

108. FDA. Plendil: prescribing information. 2012. https://www.acces sdata.fda.gov/drugsatfda_docs/label/2012/019834s025lbl.pdf. Accessed 6 Mar 2018

109. Dutch Medicines Evaluation Board (CBG). Lercanidipine HCL: product information. 2015. https://db.cbg-meb.nl/IB-teksten/ h103614.pdf. Accessed 6 Mar 2018.

110. FDA. Nicardipine hydrochloride: prescribing information. 1988. https://www.accessdata.fda.gov/drugsatfda_docs/label /2016/022276s011lbl.pdf. Accessed 6 Mar 2018.

111. FDA. Procardia XL: prescribing information. 2013. https://www. accessdata.fda.gov/drugsatfda_docs/label/2013/019684s026lbl. pdf. Accessed 6 Mar 2018.

112. FDA. Liptruzet: prescribing information. 2013. https://www. accessdata.fda.gov/drugsatfda_docs/label/2017/200153s006lbl. pdf. Accessed 6 Mar 2018.

113. FDA. Vytorin: prescribing information. 2004. https://www.acces sdata.fda.gov/drugsatfda_docs/label/2010/021687s036lbl.pdf. Accessed 6 Mar 2018.

114. FDA. Altoprev: prescribing information. 2002. https://www.acces sdata.fda.gov/drugsatfda_docs/label/2014/021316s031lbl.pdf. Accessed 6 Mar 2018.

115. FDA. Pravachol: prescribing information. 1991. https://www. accessdata.fda.gov/drugsatfda_docs/label/2011/019898s061lbl. pdf. Accessed 6 Mar 2018.

116. FDA. Crestor: prescribing information. 2003. https://www.acces sdata.fda.gov/drugsatfda_docs/label/2015/021366s032lbl.pdf. Accessed 6 Mar 2018.

117. Dutch Medicines Evaluation Board (CBG). Bezalip: summary of product characteristics. 2015. https://db.cbg-meb.nl/IB-tekst en/h15982.pdf. Accessed 6 Mar 2018.

118. Dutch Medicines Evaluation Board (CBG). Ciprofibraat Amdipharm: summary of product characteristics. 2016. https://db.cbgmeb.n1/IB-teksten/h111600.pdf. Accessed 6 Mar 2018.

119. FDA. Antara: prescribing information. 1993. https://www.acces sdata.fda.gov/drugsatfda_docs/label/2015/021695s012lbl.pdf. Accessed 6 Mar 2018.

120. FDA. Lopid: prescription information. 2016. https://www.acces sdata.fda.gov/drugsatfda_docs/label/2016/018422s055lbl.pdf. Accessed 6 Mar 2018.

121. FDA. Durlaza: prescribing information. 2015. https://www.acces sdata.fda.gov/drugsatfda_docs/label/2015/200671s000lbl.pdf. Accessed 6 Mar 2018.

122. FDA. Aggrenox: prescribing information. 1999. http://docs. boehringer-ingelheim.com/Prescribing\%20Information/PIs/ Aggrenox\%20Caps/Aggrenox.pdf. Accessed 6 Mar 2018.

123. Dutch Medicines Evaluation Board (CBG). Ascal 38 Brisper: summary of product characteristics. 2014. https://db.cbg-meb. nl/IB-teksten/h21994.pdf. Accessed 6 Mar 2018.

124. FDA. Brilinta: prescribing information. 2011. https://www. accessdata.fda.gov/drugsatfda_docs/label/2016/022433s020 lbl.pdf. Accessed 6 Mar 2018.

125. Dutch Medicines Evaluation Board (CBG). Acenocoumarol CF: summary of product characteristics. 2017. https://db.cbgmeb.nl/IB-teksten/h50674.pdf. Accessed 6 Mar 2018.

126. Dutch Medicines Evaluation Board (CBG). Fenprocoumon Sandoz: summary of product characteristics. 2017. https:// db.cbg-meb.n1/IB-teksten/h21068.pdf. Accessed 6 Mar 2018. 
127. FDA. Coumadin: prescribing information. 1954. https://www. accessdata.fda.gov/drugsatfda_docs/label/2017/009218s017 lbl.pdf. Accessed 6 Mar 2018.

128. FDA. Fragmin: prescribing information. 1994. https://www. accessdata.fda.gov/drugsatfda_docs/label/2017/020287s069 lbl.pdf. Accessed 6 Mar 2018.

129. FDA. Lovenox: prescribing information. 1993. https://www. accessdata.fda.gov/drugsatfda_docs/label/2013/020164s 102 lbl.pdf. Accessed 6 Mar 2018.

130. FDA. Heparin sodium: prescribing information. 2008. https ://www.accessdata.fda.gov/drugsatfda_docs/label/2008/01702 9s108lbl.pdf. Accessed 6 Mar 2018.

131. Dutch Medicines Evaluation Board (CBG). Fraxiparine: summary of product characteristics. 2017. https://db.cbg-meb.nl/ IB-teksten/h11876.pdf. Accessed 6 Mar 2018.

132. FDA. Arixtra: product information. 2001. https://www.acces sdata.fda.gov/drugsatfda_docs/label/2017/021345s035lbl.pdf. Accessed 6 Mar 2018

133. EMA. Pradaxa: summary of product characteristics. 2013. http://www.ema.europa.eu/docs/en_GB/document_library/ EPAR_-_Product_Information/human/000829/WC50004105 9.pdf. Accessed 6 Mar 2018.

134. FDA. Pradaxa: prescribing information. 2010. https://www. accessdata.fda.gov/drugsatfda_docs/label/2011/022512s007 lbl.pdf. Accessed 6 Mar 2018.

135. FDA. Savaysa: prescribing information. 2015. https://www. accessdata.fda.gov/drugsatfda_docs/label/2015/206316lbl. pdf. Accessed 6 Mar 2018.

136. EMA. Xarelto: summary of product characteristics. 2013. http://www.ema.europa.eu/docs/en_GB/document_library/ EPAR_-_Product_Information/human/000944/WC50005710 8.pdf. Accessed 8 Mar 2018.

137. FDA. Xarelto: prescribing information. 2011. https://www. accessdata.fda.gov/drugsatfda_docs/label/2011/202439s001 1bl.pdf. Accessed 8 Feb 2018.

138. FDA. NitroMist: prescribing information. 2006. https://www. accessdata.fda.gov/drugsatfda_docs/label/2016/021780s007 lbl.pdf. Accessed 7 Mar 2018.

139. Dutch Medicines Evaluation Board (CBG). Isosorbide dinitraat retard CF: summary of product characteristics. 2010. https:// db.cbg-meb.nl/Bijsluiters/h56834.pdf. Accessed 7 Mar 2018.
140. FDA. Monoket: prescribing information. 2014. https://www. accessdata.fda.gov/drugsatfda_docs/label/2014/020215s024 lbl.pdf. Accessed 7 Mar 2018.

141. (NVZA) NVvZ. Therapeutic Drug Monitoring Monografie. 2018. http://tdm-monografie.org/tdm-monografieen. Accessed 7 Mar 2018.

142. FDA. Cordarone: prescribing information. 2015. https://www. accessdata.fda.gov/drugsatfda_docs/label/2017/018972s053 lbl.pdf. Accessed 7 Mar 2018.

143. FDA. Nexterone: prescribing information. 2008. https://www. accessdata.fda.gov/drugsatfda_docs/label/2008/022325lbl.pdf. Accessed 7 Mar 2018.

144. FDA. Digoxin oral solution: prescribing information. 1982. https ://www.accessdata.fda.gov/drugsatfda_docs/label/2015/02164 8s008lbl.pdf. Accessed 7 Mar 2018.

145. EMA. Guideline on the investigation of drug interactions. 21 Jun 2012. http://www.ema.europa.eu/docs/en_GB/document_library/ Scientific_guideline/2012/07/WC500129606.pdf. Accessed 14 Feb 2015.

146. EMA. Harvoni: summary of product characteristics. http://www. ema.europa.eu/docs/en_GB/document_library/EPAR_-_Produ ct_Information/human/003850/WC500177995.pdf. Accessed 7 Mar 2018.

147. FDA. Harvoni: prescribing information. 2014. http://www.acces sdata.fda.gov/drugsatfda_docs/label/2014/205834s000lbl.pdf. Accessed 7 Mar 2018.

148. FDA. Olysio: prescribing information. 2014. http://www.acces sdata.fda.gov/drugsatfda_docs/label/2014/205123s002lbledt.pdf. Accessed 7 Mar 2018.

149. FDA. Epclusa: prescribing information. 2016. http://www.acces sdata.fda.gov/drugsatfda_docs/label/2016/208341s000lbl.pdf. Accessed 7 Mar 2018.

150. EMA. Sovaldi product information. 2015. http://www.ema.europ a.eu/docs/en_GB/document_library/EPAR_-_Product_Infor mation/human/002798/WC500160597.pdf. Accessed 7 Mar 2018.

151. Roden DM, George AL Jr. The genetic basis of variability in drug responses. Nat Rev Drug Discov. 2002;1:37-44.

152. Back D. Update on some key drug interaction issues. EASL 2017. EMW - Practical management of drug-drug interaction in patients treated with DAA, Friday 21 April 2017. 